\title{
A methodology to constrain carbon dioxide emissions from coal-fired power plants using satellite observations of co-emitted nitrogen dioxide
}

\author{
Fei Liu ${ }^{1,2}$, Bryan N. Duncan ${ }^{2}$, Nickolay A. Krotkov ${ }^{2}$, Lok N. Lamsal ${ }^{1,2}$, Steffen Beirle ${ }^{3}$, Debora Griffin ${ }^{4}$, \\ Chris A. McLinden ${ }^{4}$, Daniel L. Goldberg ${ }^{5}$, and Zifeng $\mathbf{L u}^{5}$ \\ ${ }^{1}$ Universities Space Research Association (USRA), Goddard Earth Sciences Technology and Research \\ (GESTAR), Columbia, MD, USA \\ ${ }^{2}$ NASA Goddard Space Flight Center, Greenbelt, MD, USA \\ ${ }^{3}$ Max-Planck-Institut für Chemie, Mainz, Germany \\ ${ }^{4}$ Air Quality Research Division, Environment and Climate Change Canada, Toronto, ON, Canada \\ ${ }^{5}$ Energy Systems Division, Argonne National Laboratory, Lemont, IL, USA
}

Correspondence: Fei Liu (fei.liu@ nasa.gov)

Received: 31 May 2019 - Discussion started: 8 July 2019

Revised: 29 October 2019 - Accepted: 25 November 2019 - Published: 3 January 2020

\begin{abstract}
We present a method to infer $\mathrm{CO}_{2}$ emissions from individual power plants based on satellite observations of coemitted nitrogen dioxide $\left(\mathrm{NO}_{2}\right)$, which could serve as complementary verification of bottom-up inventories or be used to supplement these inventories. We demonstrate its utility on eight large and isolated US power plants, where accurate stack emission estimates of both gases are available for comparison. In the first step of our methodology, we infer nitrogen oxides $\left(\mathrm{NO}_{x}\right)$ emissions from US power plants using Ozone Monitoring Instrument (OMI) $\mathrm{NO}_{2}$ tropospheric vertical column densities (VCDs) averaged over the ozone season (May-September) and a "top-down" approach that we previously developed. Second, we determine the relationship between $\mathrm{NO}_{x}$ and $\mathrm{CO}_{2}$ emissions based on the direct stack emissions measurements reported by continuous emissions monitoring system (CEMS) programs, accounting for coal quality, boiler firing technology, $\mathrm{NO}_{x}$ emission control device type, and any change in operating conditions. Third, we estimate $\mathrm{CO}_{2}$ emissions for power plants using the OMIestimated $\mathrm{NO}_{x}$ emissions and the CEMS $\mathrm{NO}_{x} / \mathrm{CO}_{2}$ emission ratio. We find that the $\mathrm{CO}_{2}$ emissions estimated by our satellite-based method during 2005-2017 are in reasonable agreement with the US CEMS measurements, with a relative difference of $8 \% \pm 41 \%$ (mean \pm standard deviation). The broader implication of our methodology is that it has the
\end{abstract}

potential to provide an additional constraint on $\mathrm{CO}_{2}$ emissions from power plants in regions of the world without reliable emissions accounting. We explore the feasibility by comparing the derived $\mathrm{NO}_{x} / \mathrm{CO}_{2}$ emission ratios for the US with those from a bottom-up emission inventory for other countries and applying our methodology to a power plant in South Africa, where the satellite-based emission estimates show reasonable consistency with other independent estimates. Though our analysis is limited to a few power plants, we expect to be able to apply our method to more US (and world) power plants when multi-year data records become available from new OMI-like sensors with improved capabilities, such as the TROPOspheric Monitoring Instrument (TROPOMI), and upcoming geostationary satellites, such as the Tropospheric Emissions: Monitoring Pollution (TEMPO) instrument.

\section{Introduction}

Thermal power plants, particularly coal-fired power plants, are among the largest anthropogenic $\mathrm{CO}_{2}$ emitters, contributing $\sim 40 \%$ of energy-related $\mathrm{CO}_{2}$ emissions globally in 2010 (Janssens-Maenhout et al., 2017). Coal-fired power plants are expected to be one of the primary contributors of $\mathrm{CO}_{2}$ 
emissions in the coming decades because of abundant world coal reserves (Shindell and Faluvegi, 2010). Therefore, it is important to accurately monitor global $\mathrm{CO}_{2}$ emissions from power production in order to better predict climate change (Shindell and Faluvegi, 2010) and to support the development of effective climate mitigation strategies.

$\mathrm{CO}_{2}$ emissions from power plants are typically quantified based on bottom-up approaches using fuel consumption and fuel quality, though fuel properties are not always well known, resulting in uncertainties in the estimated $\mathrm{CO}_{2}$ emissions for individual plants (Wheeler and Ummel, 2008). Even for US power plants that are considered to have the most accurate information on fuel usage among world nations, the difference between emissions estimated based on fuel usage and those reported as part of continuous emissions monitoring system (CEMS) programs is typically about $20 \%$ (Ackermann and Sundquist, 2008). Thus, emission estimates based on independent data sources, such as satellite observations, are a desirable complement for the validation and improvement of the current $\mathrm{CO}_{2}$ emissions inventories, especially in countries without CEMS data, which is the case in most of the world.

Anthropogenic $\mathrm{CO}_{2}$ emissions have been estimated from space-based $\mathrm{CO}_{2}$ observations, but the existing satellite $\mathrm{CO}_{2}$ sensors are designed to provide constraints on natural $\mathrm{CO}_{2}$ sources and sinks (Basu et al., 2013; Houweling et al., 2015) and thus their capability for monitoring anthropogenic point sources is limited (Nassar et al., 2017). Observations from sensors, including the Scanning Imaging Absorption Spectrometer for Atmospheric Chartography (SCIAMACHY; Burrows et al., 1995), Greenhouse gases Observing SATellite (GOSAT; Yokota et al., 2009), and Orbiting Carbon Observatory-2 (OCO-2; Crisp, 2015), show statistically significant enhancements over metropolitan regions (Kort et al., 2012; Schneising et al., 2013; Janardanan et al., 2016; Buchwitz et al., 2018; Reuter et al., 2019; Wang et al., 2018). However, very few studies have focused on individual point sources. Bovensmann et al. (2010) and Velazco et al. (2011) presented a promising satellite remote-sensing concept to infer $\mathrm{CO}_{2}$ emissions for power plants based on the atmospheric $\mathrm{CO}_{2}$ column distribution. Nassar et al. (2017) presented the first quantification of $\mathrm{CO}_{2}$ emissions from individual power plants using OCO-2 observations. However, because of the narrow swath $(\sim 10 \mathrm{~km}$ at nadir) and $16 \mathrm{~d}$ repeat cycle of the OCO-2 sensor, the number of clear-day overpasses is too small to allow for the development of a global $\mathrm{CO}_{2}$ emissions database.

In contrast to $\mathrm{CO}_{2}$, inferring $\mathrm{NO}_{x}$ emissions from individual power plants using satellite $\mathrm{NO}_{2}$ column retrievals has been done with a higher degree of confidence (e.g., Duncan et al., 2013; de Foy et al., 2015). The Dutch-Finnish Ozone Monitoring Instrument (OMI) on NASA's Earth Observing System Aura spacecraft (Schoeberl et al., 2006) provides near-daily, global $\mathrm{NO}_{2}$ tropospheric vertical column densities (VCDs) at a spatial resolution of $13 \times 24 \mathrm{~km}^{2}$ (at nadir)
(Levelt et al., 2006, 2018; Krotkov et al., 2017), which allows emission signals from individual power plants to be resolved. Beirle et al. (2011) first analyzed isolated large sources (i.e., megacities and the US Four Corners power plant) by averaging OMI $\mathrm{NO}_{2}$ tropospheric VCDs separately for different wind directions, which allows for the estimation of $\mathrm{NO}_{x}$ emissions and lifetimes by fitting an exponentially modified Gaussian function. Several follow-up studies (e.g., de Foy et al., 2015; Lu et al., 2015 and Goldberg et al., 2019a) further developed this approach and inferred $\mathrm{NO}_{x}$ emissions from isolated power plants and cities. More recently, we advanced this approach for sources located in polluted areas to infer $\mathrm{NO}_{x}$ emissions for 17 power plants and 53 cities across China and the US (Liu et al., 2016, 2017).

Since $\mathrm{NO}_{x}$ is co-emitted with $\mathrm{CO}_{2}, \mathrm{NO}_{x}$ emissions inferred from satellite data may be used to estimate $\mathrm{CO}_{2}$ emissions from thermal power plants. Previous analyses estimated regional $\mathrm{CO}_{2}$ emissions based on satellite-derived $\mathrm{NO}_{x}$ emissions and the $\mathrm{NO}_{x}$ to $\mathrm{CO}_{2}$ emission ratios from bottom-up emission inventories (Berezin et al., 2013; Konovalov et al., 2016; Goldberg et al., 2019b) or co-located satellite retrievals of $\mathrm{CO}_{2}$ and $\mathrm{NO}_{2}$ (Reuter et al., 2014). Hakkarainen et al. (2016) confirmed the spatial correlation between $\mathrm{CO}_{2}$ spatial anomalies and $\mathrm{OMI} \mathrm{NO}_{2} \mathrm{VCD}$ enhancements at the regional scale using satellite observations at higher resolution. Hakkarainen et al. (2019) also showed how overlapping OCO-2 $\mathrm{CO}_{2}$ data and data of $\mathrm{NO}_{2}$ from the recently launched (October 2017) European Union Copernicus Sentinel-5 precursor TROPOspheric Monitoring Instrument (TROPOMI; Veefkind et al., 2012) can be used to identify small-scale anthropogenic $\mathrm{CO}_{2}$ signatures.

More recently, the co-located regional enhancements of $\mathrm{CO}_{2}$ observed by OCO-2 and $\mathrm{NO}_{2}$ observed by TROPOMI were analyzed to infer localized $\mathrm{CO}_{2}$ emissions for six hotspots including one power plant globally (Reuter et al., 2019). As emissions plumes are significantly longer than the swath width of OCO-2 $(10 \mathrm{~km})$, OCO-2 sees only cross sections of plumes, which may not be sufficient to infer emission strengths. Because power plant emissions can have substantial temporal variations (Velazco et al., 2011) and the cross-sectional $\mathrm{CO}_{2}$ fluxes are valid only for OCO-2 overpass times, the cross-sectional fluxes may not adequately represent the annual or monthly averages, which are required for the development of climate mitigation strategies. In addition, the cross-sectional fluxes may not be a good approximation for emission strengths if meteorological conditions are not taken into account (Varon et al., 2018). As compared to the method proposed in this study, Reuter's method has the advantage of not requiring a priori emission information. However, there are currently no satellite instruments with a wide enough swath to allow wider application of Reuter's method.

In this study, we present a method to estimate $\mathrm{CO}_{2}$ emissions from individual power plants using $\mathrm{OMI} \mathrm{NO}_{2}$ observations and auxiliary CEMS information necessary to estimate $\mathrm{NO}_{x}$ to $\mathrm{CO}_{2}$ emission ratios. Such estimates could serve as 


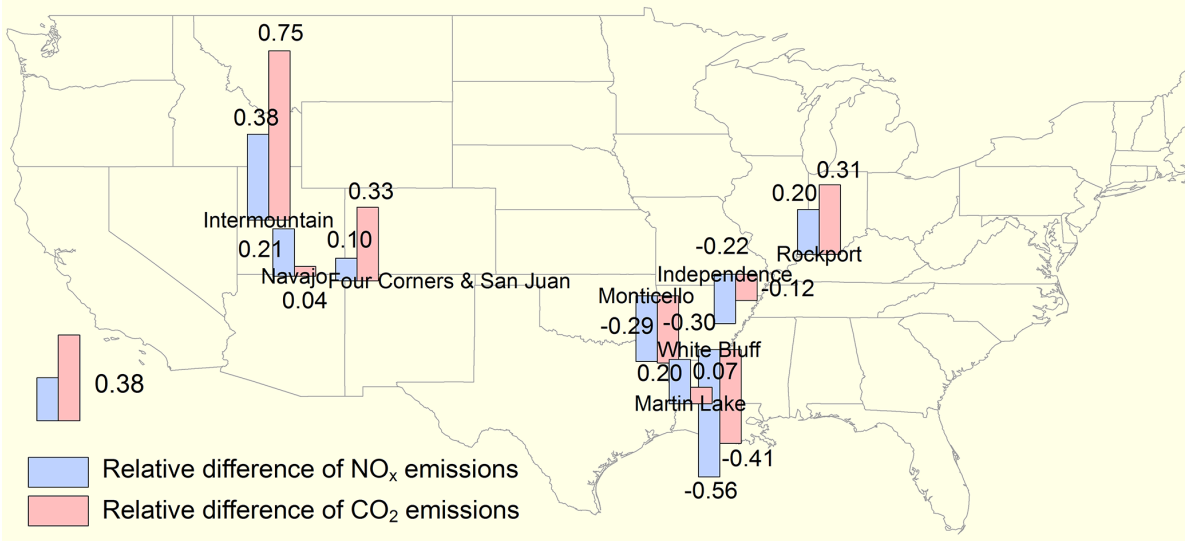

Figure 1. Locations of the power plants investigated in this study. The bar charts denote the relative differences, defined as $\left(E^{\text {Sat }}-\right.$ $\left.E^{\mathrm{CEMS}}\right) / E^{\mathrm{CEMS}}$, averaged over 2005-2017 for $\mathrm{NO}_{x}$ (blue) and $\mathrm{CO}_{2}$ (red) emissions. The upward and downward bars represent positive and negative differences, respectively. The Monticello power plant installed SNCR to control $\mathrm{NO}_{x}$ emissions in 2008. The other power plants are not equipped with post-combustion $\mathrm{NO}_{x}$ control devices.

complementary verification of bottom-up $\mathrm{CO}_{2}$ inventories or as a supplement to these inventories. For instance, Liu et al. (2018) used satellite data of $\mathrm{SO}_{2}$ to identify large $\mathrm{SO}_{2}$ sources that were missing from a bottom-up emissions inventory and created a merged bottom-up and top-down $\mathrm{SO}_{2}$ emissions inventory. We apply our approach to US power plants, which have an exceptionally detailed CEMS database of $\mathrm{NO}_{x}$ and $\mathrm{CO}_{2}$ emissions, in order to validate our method. Using auxiliary CEMS information, we explore the relationship between $\mathrm{NO}_{x}$ and $\mathrm{CO}_{2}$ emissions for individual power plants, assessing variations in the ratio associated with coal quality, boiler firing type, $\mathrm{NO}_{x}$ emission control device technology, and changes in operating conditions. Understanding the causes of these variations will allow for better-informed assumptions when applying our method to power plants that have no or uncertain information on the factors that affect their emissions ratios. We discuss the uncertainties and applications of our approach and the potential of $\mathrm{NO}_{2}$ datasets from new and upcoming satellite instruments, which will improve the utility of our method for inferring $\mathrm{CO}_{2}$ emissions from power plants around the world. Finally, we discuss future research directions.

\section{Method}

In this section, we present our method to infer $\mathrm{CO}_{2}$ emissions $\left(E_{\mathrm{CO}_{2}}^{\mathrm{Sat}}\right)$ from satellite-derived $\mathrm{NO}_{x}$ emissions $\left(E_{\mathrm{NO}_{x}}^{\mathrm{Sat}}\right)$ for individual coal-fired power plants using the following equation:

$E_{\mathrm{CO}_{2}, y}^{\mathrm{Sat}}=\frac{E_{\mathrm{NO}_{x, y}}^{\mathrm{Sat}}}{\operatorname{ratio}_{i, y}^{\mathrm{CEMS}}}$,

where $i$ represents coal type and $y$ represents the target year. We demonstrate our method on US power plants since there are accurate CEMS stack measurements of $\mathrm{NO}_{x}$ and $\mathrm{CO}_{2}$ emissions with which to validate $E_{\mathrm{CO}_{2}}^{\mathrm{Sat}}$. In Sect. 2.1, we describe how we estimate $E_{\mathrm{NO}_{x}}^{\mathrm{Sat}}$ from $\mathrm{OMI} \mathrm{NO}_{2}$ tropospheric VCD observations. In Sect. 2.2, we discuss how we estimate the ratio of $\mathrm{NO}_{x}$ to $\mathrm{CO}_{2}$ emissions ( ratio $_{y}^{\mathrm{CEMS}}=$ $E_{\mathrm{NO}_{x}, y}^{\mathrm{CEMS}} / E_{\mathrm{CO}_{2}, y}^{\mathrm{CEMS}}$ ) from CEMS stack measurements in the US Emissions and Generation Resource Integrated Database (eGRID; USEPA, 2018). Since post-combustion $\mathrm{NO}_{x}$ control systems, including selective non-catalytic reduction (SNCR) and selective catalytic reduction (SCR), change the relationship between $E_{\mathrm{NO}_{x}}^{\mathrm{CEMS}}$ and $E_{\mathrm{CO}_{2}}^{\mathrm{CEMS}}$, we present separate methods to determine ratio ${ }_{y}^{\text {CEMS }}$ for power plants without and with post-combustion $\mathrm{NO}_{x}$ control systems in Sect. 2.2.1 and 2.2.2, respectively. We discuss the validation of the estimated $E_{\mathrm{CO}_{2}}^{\mathrm{Sat}}$ in Sect. 3 .

\subsection{Estimating satellite-derived $\mathrm{NO}_{x}$ emissions $\left(E_{\mathrm{NO}_{x}}^{\mathrm{Sat}}\right)$}

From all US coal-fired power plants, we selected 21 power plants for estimating $E_{\mathrm{NO}_{x}}^{\mathrm{Sat}}$. We chose these plants based on the magnitude of their annual emissions (i.e., $E_{\mathrm{NO}_{x}}^{\mathrm{CEMS}}$ $>10 \mathrm{Gg} \mathrm{yr}^{-1}$ in 2005) and relative isolation from other large sources to avoid "contamination" of a power plant's $\mathrm{NO}_{x}$ plume. Power plants located in urban areas (i.e., within a radius of $100 \mathrm{~km}$ from a city center), or clustered in close proximity (i.e., $50 \mathrm{~km}$ ) with other large industrial plants were excluded by visual inspection using satellite imagery from Google Earth. We used the top 200 largest US cities (ranked by 2018 population as estimated by the United States Census Bureau, available at https://en.wikipedia.org/wiki/List_ of_United_States_cities_by_population, last access: 10 December 2019) to select power plants. As discussed below, we were able to estimate $E_{\mathrm{NO}_{x}}^{\mathrm{Sat}}$ for 8 of the 21 plants. The loca- 
(a) Calm wind

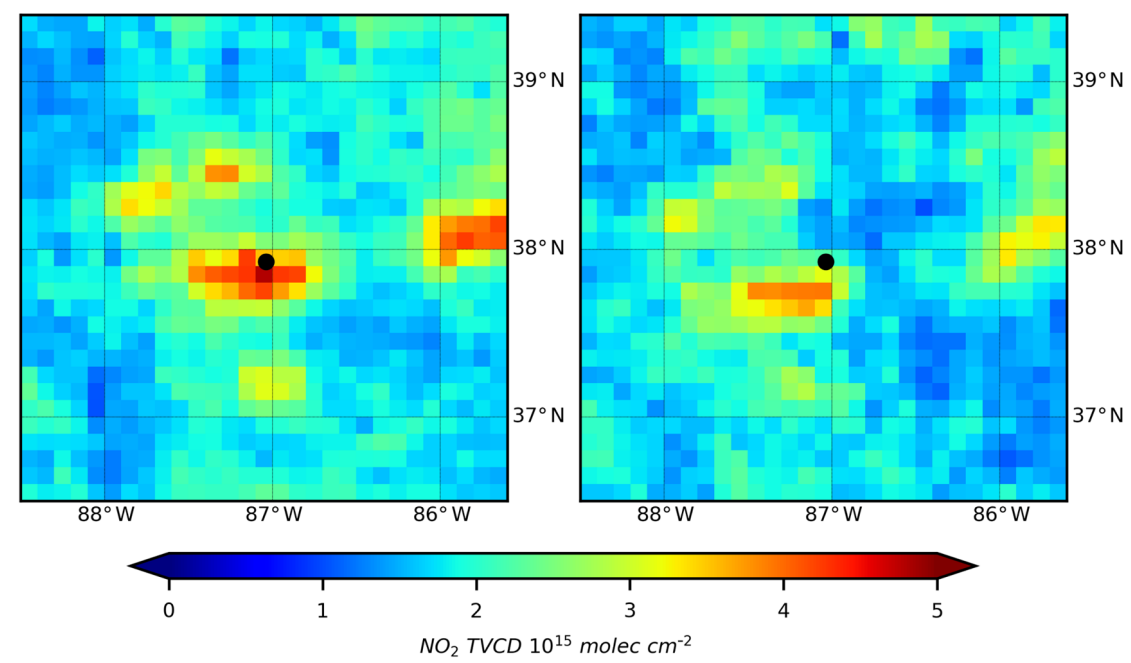

(c) Difference

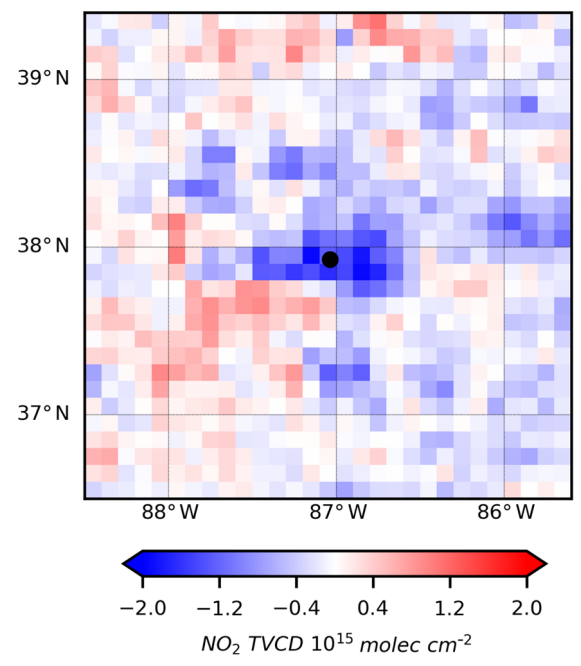

(d)

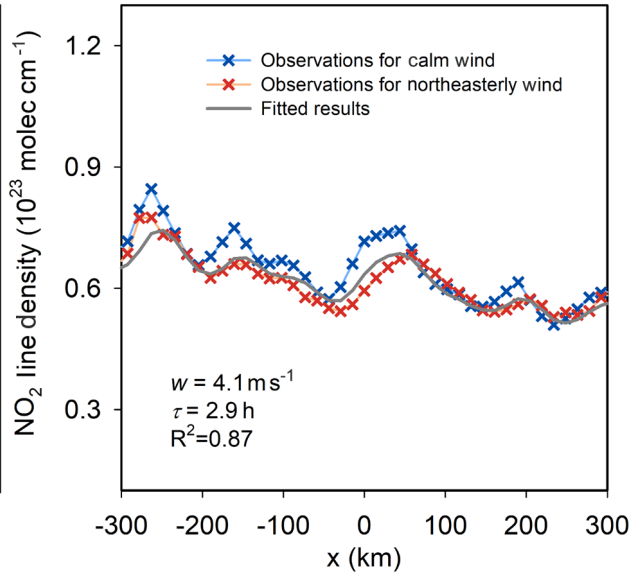

Figure 2. Mean $\mathrm{OMI} \mathrm{NO}_{2}$ tropospheric VCDs around the Rockport power plant (Indiana, USA) for (a) calm conditions, (b) northeasterly wind and (c) their difference (northeasterly minus calm) for the period of 2005-2017. The location of Rockport is labeled by a black dot. (d) $\mathrm{NO}_{2}$ line densities around Rockport. Crosses are $\mathrm{NO}_{2}$ line densities for calm (blue) and northeasterly winds (red) as function of the distance $x$ to Rockport center. The grey line is the fitted results for $\mathrm{NO}_{2}$ line densities for northeasterly winds. The numbers indicate the net mean wind velocities (windy minus calm) from MERRA-2 $(w)$, the fitted lifetime $(\tau)$, and the coefficient of determination $\left(R^{2}\right)$ of the fit.

tions of the 8 plants are shown in Fig. 1 and given in Table S1 in the Supplement.

We followed the method of Liu et al. $(2016,2017)$ to estimate $E_{\mathrm{NO}_{x}}^{\mathrm{Sat}}$ for 2005 to 2017 . In our analysis, we used $\mathrm{OMI} \mathrm{NO}_{2}$ tropospheric VCDs from the NASA OMI standard product, version 3.1 (Krotkov et al., 2017), together with meteorological wind information from the Modern-Era Retrospective Analysis for Research and Applications, version 2 (MERRA-2; Gelaro et al., 2017). We only analyzed data for the ozone season (May-September), in order to exclude winter data, which have larger uncertainties and longer $\mathrm{NO}_{x}$ lifetimes. As in our previous study (Liu et al., 2017), we calculated one-dimensional $\mathrm{NO}_{2}$ "line densities", i.e., $\mathrm{NO}_{2} \mathrm{~cm}^{-1}$, as function of distance for each wind direction separately by integration of the mean $\mathrm{NO}_{2}$ VCDs (i.e., $\mathrm{NO}_{2} \mathrm{~cm}^{-2}$ ) perpendicular to the wind direction. We then used the changes of $\mathrm{NO}_{2}$ line densities under calm wind conditions (wind speed $<2 \mathrm{~m} \mathrm{~s}^{-1}$ below $500 \mathrm{~m}$ ) and windy conditions (wind speed $>2 \mathrm{~m} \mathrm{~s}^{-1}$ ) to fit the effective $\mathrm{NO}_{x}$ lifetime. We then estimated the average $\mathrm{NO}_{2}$ total mass integrated around a power plant on the basis of the 3-year mean VCDs, in agreement with previous studies (Fioletov et al., 2011; Lu et al., 2015). The $\mathrm{NO}_{2}$ total mass was scaled by a factor of 1.32 in order to derive total $\mathrm{NO}_{x}$ mass, following Beirle et al. (2011). The uncertainty associated with the $\mathrm{NO}_{x} / \mathrm{NO}_{2}$ ratio has been discussed in detail in Sect. 3 of the Supplement to Liu et 
al. (2016). The 3-year average $E_{\mathrm{NO}_{x}}^{\mathrm{Sat}}$ was derived from the corresponding 3-year average $\mathrm{NO}_{x}$ mass divided by the average $\mathrm{NO}_{x}$ lifetime of the entire study period (Liu et al., 2017). Fitting results of insufficient quality (e.g., correlation coefficient of the fitted and observed $\mathrm{NO}_{2}$ distributions <0.9) were excluded from this analysis, consistent with the criteria in Sect. 2.2 of Liu et al. (2016). This final filtering left 18 power plants, of which 8 had valid results for all consecutive 3-year periods between 2005 and 2017. More details of the approach are documented in Liu et al. (2017). The fitted lifetimes and other fitting parameters for all power plants are given in Table S1.

We use the Rockport power plant $\left(37.9^{\circ} \mathrm{N}, 87.0^{\circ} \mathrm{W}\right)$ in Indiana to demonstrate our approach. This power plant is particularly well suited for estimating $E_{\mathrm{NO}_{x}}^{\mathrm{Sat}}$ because it is a large and isolated $\mathrm{NO}_{x}$ point source. Figure 2 presents the $\mathrm{NO}_{2}$ VCD map around Rockport and the fitted results. Figure 3 displays $E_{\mathrm{NO}_{x}}^{\mathrm{Sat}}$ based on 3-year mean VCDs. Each 3year period is represented by the middle year with an asterisk (e.g., 2006* denotes the period from 2005 to 2007). For comparison to $E_{\mathrm{NO}_{x}}^{\mathrm{Sat}}, E_{\mathrm{NO}_{x}}^{\mathrm{CEMS}}$ is from Air Markets Program Data (available at: https://ampd.epa.gov/ampd/, last access: 1 May 2019) and averaged over the period of May to September. For this particular plant, $E_{\mathrm{NO}_{x}}^{\mathrm{Sat}}$ is always higher than $E_{\mathrm{NO}_{x}}^{\mathrm{CEMS}}$ during the entire period, except the last 2 years. The coefficient of determination for the entire period is $R^{2}=$ 0.68 . The relative differences for individual 3-year means (defined as $\left.\left(E_{\mathrm{NO}_{x}}^{\mathrm{Sat}}-E_{\mathrm{NO}_{x}}^{\mathrm{CEMS}}\right) / E_{\mathrm{NO}_{x}}^{\mathrm{CEMS}}\right)$ range from $-20 \%$ to $41 \%$ because of the uncertainties of $E_{\mathrm{NO}_{x}}^{\mathrm{Sat}}$, as discussed in Sect. 3.2. Both datasets present a declining trend from $2012^{*}$. The total declines of $45 \%$ and $26 \%$ since $2012 *$ in $E_{\mathrm{NO}_{x}}^{\mathrm{Sat}}$ and $E_{\mathrm{NO}_{x}}^{\mathrm{CEMS}}$ are attributed to the $25 \%$ decrease in net electricity generation for the plant. The average relative difference of $E_{\mathrm{NO}_{x}}^{\mathrm{Sat}}$ and $E_{\mathrm{NO}_{x}}^{\mathrm{CEMS}}$ for the eight plants in this study is $0 \% \pm 33 \%$, ranging from $-58 \%$ to $72 \%$ for individual 3 -year periods (Fig. 1).

\subsection{Estimating $\mathrm{NO}_{x}$ to $\mathrm{CO}_{2}$ emission ratios using CEMS data (ratio ${ }^{\text {CEMS }}$ )}

We determined the relationship between $E_{\mathrm{NO}_{x}}^{\mathrm{CEMS}}$ and $E_{\mathrm{CO}_{2}}^{\mathrm{CEMS}}$ for coal-fired power plants using eGRID information about each plant's net electric generation, boiler firing technology (e.g., tangential or wall-fired boiler), $\mathrm{NO}_{x}$ control device type, fossil fuel category (i.e., coal, oil, gas, and other), and coal quality (i.e., bituminous, lignite, subbituminous, refined, and waste coal). We used data of power plants with more than $99 \%$ of the fuel burned being coal, as reported in eGRID. We analyzed the relationship between $E_{\mathrm{NO}_{x}}^{\mathrm{CEMS}}$ and $E_{\mathrm{CO}_{2}}^{\mathrm{CEMS}}$ by coal type, as emission characteristics vary widely by coal type.

The eGRID includes two datasets of emissions for $\mathrm{NO}_{x}$ and $\mathrm{CO}_{2}$ : (1) calculated from fuel consumption data and (2) observed by stack monitoring (i.e., $E_{\mathrm{NO}_{x}}^{\mathrm{CEMS}}$ and $E_{\mathrm{CO}_{2}}^{\mathrm{CEMS}}$ ).

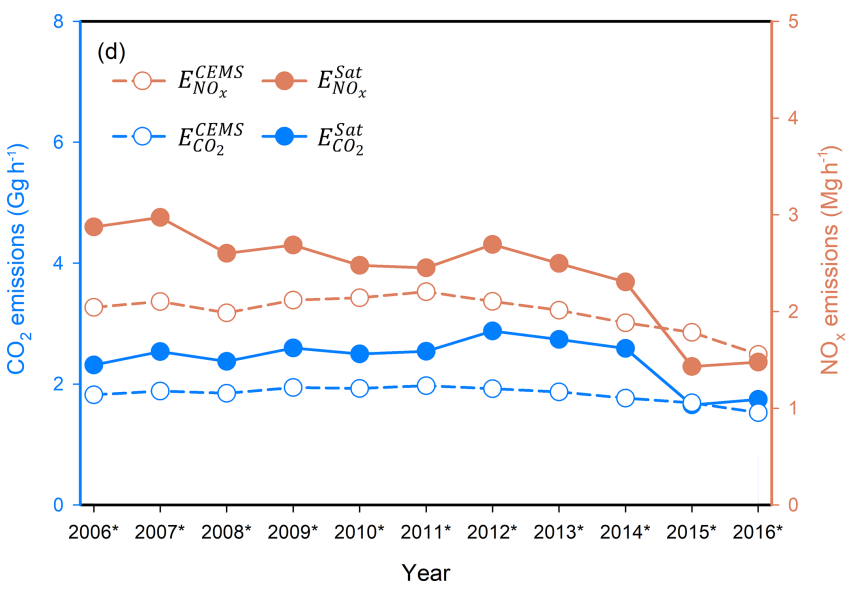

Figure 3. $E_{\mathrm{NO}_{x}}^{\mathrm{Sat}}\left(\mathrm{Mgh}^{-1}\right.$; orange solid line, right axis $)$ and $E_{\mathrm{CO}_{2}}^{\mathrm{Sat}}$ $\left(\mathrm{Gg} \mathrm{h}^{-1}\right.$; blue solid line, left axis) for the Rockport power plant from 2005 to 2017. $E_{\mathrm{NO}_{x}}^{\mathrm{CEMS}}$ and $E_{\mathrm{CO}_{2}}^{\mathrm{CEMS}}$ (dashed lines) are also shown. The 3 -year periods are represented by the middle year with an asterisk (e.g., 2006* denotes the period from 2005 to 2007).

Here we focus on eGRID CEMS data, as $E_{\mathrm{NO}_{x}}^{\mathrm{CEMS}}$ are reported to be highly accurate with an error of less than $5 \%$ (e.g., Glenn et al., 2003). $E_{\mathrm{CO}_{2}}^{\mathrm{CEMS}}$ may have larger uncertainties than fuel-based emissions estimates because of uncertainties in the calculation of flue gas flow (Majanne et al., 2015). Nevertheless, we used $E_{\mathrm{CO}_{2}}^{\mathrm{CEMS}}$ to relate $\mathrm{NO}_{x}$ emissions to $\mathrm{CO}_{2}$ emissions, since the primary uncertainty of $E_{\mathrm{NO}_{x}}^{\mathrm{CEMS}}$ and $E_{\mathrm{CO}_{2}}^{\mathrm{CEMS}}$ arises from the calculation of the flue gas flow, which will cancel in ratio ${ }^{\mathrm{CEMS}}$.

\subsubsection{Coal-fired power plants without post-combustion $\mathrm{NO}_{x}$ control systems}

We initially limited our analysis to $E_{\mathrm{NO}_{x}}^{\mathrm{CEMS}}$ and $E_{\mathrm{CO}}^{\mathrm{CEMS}}$ from coal-fired power plants without post-combustion $\mathrm{NO}_{x}$ control systems in operation in a given year (Table 1). We find that $E_{\mathrm{NO}_{x}}^{\mathrm{CEMS}}$ and $E_{\mathrm{CO}_{2}}^{\mathrm{CEMS}}$ have a strong linear relationship (Fig. 4). In Fig. 4a, we compare $E_{\mathrm{NO}_{x}}^{\mathrm{CEMS}}$ and $E_{\mathrm{CO}_{2}}^{\mathrm{CEMS}}$ from power plants (using bituminous coal) by boiler firing type in 2005. We use bituminous coal-fired plants for illustration, as bituminous coal is the most widely used coal in US power plants. We analyzed power plants that use cyclone or cell burner boilers separately and exclude them in Fig. 4 because they typically produce higher $\mathrm{NO}_{x}$ emissions than other boiler types (USEPA, 2009; available at: https: //www3.epa.gov/ttn/chief/ap42/ch01/index.html, last access: 1 April 2019). A strong linear relationship between $E_{\mathrm{NO}_{x}}^{\mathrm{CEMS}}$ and $E_{\mathrm{CO}_{2}}^{\mathrm{CEMS}}$ is evident with excellent correlation $\left(R^{2}=0.93\right.$, $N=278)$, regardless of boiler firing type. Similar linear relationships exist for other years (e.g., year 2016 in Fig. 4b) and other types of coal (Table 1). The slope of the regression of $E_{\mathrm{NO}_{x}}^{\mathrm{CEMS}}$ and $E_{\mathrm{CO}_{2}}^{\mathrm{CEMS}}$, ratio ${ }_{\text {regressed }}^{\mathrm{CEMS}}$, is assumed by setting 
Table 1. The slope (ratio ${ }_{\text {regressed }}^{\text {CEMS }}$ ), coefficient of determination, standard deviation, and sample number of the linear regression of $E_{\mathrm{NO}_{x}}^{\mathrm{CEMS}}$ and $E_{\mathrm{CO}_{2}}^{\mathrm{CEMS}}$ by year for all US power plants without post-combustion $\mathrm{NO}_{x}$ control devices from 2005 to 2016.

\begin{tabular}{|c|c|c|c|c|c|}
\hline Coal type & Year & ratio $_{\text {regressed }}^{C E M S}$ & $R^{2}$ & $\begin{array}{l}\text { Standard } \\
\text { deviation }\end{array}$ & $\begin{array}{r}\text { Sample } \\
\text { number* }\end{array}$ \\
\hline \multirow[t]{7}{*}{ Bituminous } & 2005 & 1.74 & 0.93 & 0.63 & 278 \\
\hline & 2007 & 1.75 & 0.91 & 0.68 & 286 \\
\hline & 2009 & 1.49 & 0.88 & 0.64 & 241 \\
\hline & 2010 & 1.48 & 0.86 & 0.60 & 235 \\
\hline & 2012 & 1.33 & 0.87 & 0.56 & 190 \\
\hline & 2014 & 1.28 & 0.87 & 0.41 & 136 \\
\hline & 2016 & 1.20 & 0.87 & 0.45 & 66 \\
\hline \multirow[t]{7}{*}{ Subbituminous } & 2005 & 1.31 & 0.65 & 0.73 & 226 \\
\hline & 2007 & 1.18 & 0.61 & 0.61 & 221 \\
\hline & 2009 & 1.02 & 0.66 & 0.56 & 230 \\
\hline & 2010 & 1.00 & 0.67 & 0.59 & 216 \\
\hline & 2012 & 0.93 & 0.74 & 0.51 & 200 \\
\hline & 2014 & 0.89 & 0.74 & 0.39 & 165 \\
\hline & 2016 & 0.84 & 0.70 & 0.39 & 111 \\
\hline \multirow[t]{7}{*}{ Lignite } & 2005 & 0.91 & 0.74 & 0.33 & 20 \\
\hline & 2007 & 0.86 & 0.82 & 0.35 & 22 \\
\hline & 2009 & 0.88 & 0.91 & 0.32 & 16 \\
\hline & 2010 & 0.83 & 0.94 & 0.37 & 18 \\
\hline & 2012 & 0.76 & 0.91 & 0.40 & 15 \\
\hline & 2014 & 0.82 & 0.92 & 0.37 & 12 \\
\hline & 2016 & 0.73 & 0.78 & 0.09 & 9 \\
\hline
\end{tabular}

* The sample number generally decreases from 2005 to 2016 as power plants installed post-combustion $\mathrm{NO}_{x}$ control devices over time.

the intercept to zero. Table 1 shows ratio regressed $, i, y_{\text {by coal }}^{\text {CEMS }}$ type and year. In Sect. 3.1, ratio ${ }_{\text {regressed, } i, y}^{\text {CEMS will be applied }}$ to approximate ratio ${ }_{i, y}^{\text {CEMS }}$ when estimating $E_{\mathrm{CO}_{2}}^{\mathrm{Sat}}$ from $E_{\mathrm{NO}_{x}}^{\mathrm{Sat}}$ for the eight plants (Fig. 1) for years before post-combustion control systems were in operation.

The ratio regressed $_{\text {Calue for power plants using bituminous }}^{\text {CEMS }}$ coal decreased from 2005 (Fig. 4a) to 2016 (Fig. 4b) by $31 \%$ on average because of reductions in $\mathrm{NO}_{x}$ emission factors associated with improvements in boiler operations, such as by optimizing furnace design and operating conditions. The $\mathrm{NO}_{x}$ emissions factors, defined as $\mathrm{NO}_{x}$ emission rates per net electricity generation $\left(\mathrm{Gg} \mathrm{TW} \mathrm{h}^{-1}\right)$, declined by $33 \%$ from 2005 to 2016 (Fig. 4c). We interpolated ratio ${ }_{\text {regressed }}^{\text {CEMS }}$ to get year-specific ratios by coal type for the entire study period, as eGRID data are only available for some years (i.e., 2005, 2007, 2009, 2010, 2012, 2014, and 2016).

In addition, ratio regressed shows significant variation by

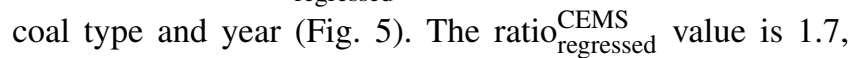
1.3 , and $0.91 \mathrm{Gg} \mathrm{NO}_{x} / \mathrm{TgCO}_{2}$ for bituminous, subbituminous, and lignite coal types in 2005 , respectively. A reduction over time in ratio regressed $_{\text {CEMS }}$ is observed for all coal types (Fig. 5). The ratio ${ }_{\text {regressed }}^{\text {CEMS value displays a large decrease of }}$
$31 \%, 36 \%$ and $20 \%$ from 2005 to 2016 for bituminous, subbituminous, and lignite coal types, respectively.

\subsubsection{Coal-fired power plants with post-combustion NO $x$ control systems}

Here, we describe how we estimated ratio ${ }^{\text {CEMS }}$ for the entire study period for plants that had post-combustion $\mathrm{NO}_{x}$ control systems installed at some time during our study period, 2005-2017. The estimation is based on ratio CEMS $_{\text {regressed }}$ derived in Sect. 2.2.1 for plants without post-combustion control systems in operation. We introduce a $\mathrm{NO}_{x}$ removal efficiency parameter, $f$, to adjust ratio regressed for years $^{\text {CEMS }}$ after the installation of post-combustion control systems, ratio ${ }^{\text {EMMS-estimated: }}$

$\operatorname{ratio}_{i, y}^{\text {CEMS-estimated }}=$ ratio $_{\text {regressed }, i, y}^{\text {CEMS }} \times,\left(1-f_{y}\right)$,

$f$ is commonly measured for individual power plants to describe the performance of their post-combustion $\mathrm{NO}_{x}$ control systems. It is directly reported by some power plant databases, such as the China coal-fired Power plant Emissions Database (CPED; Liu et al., 2015). For databases that do not report $f$, like eGRID used in this study, one can estimate it for an individual power plant by first estimating 

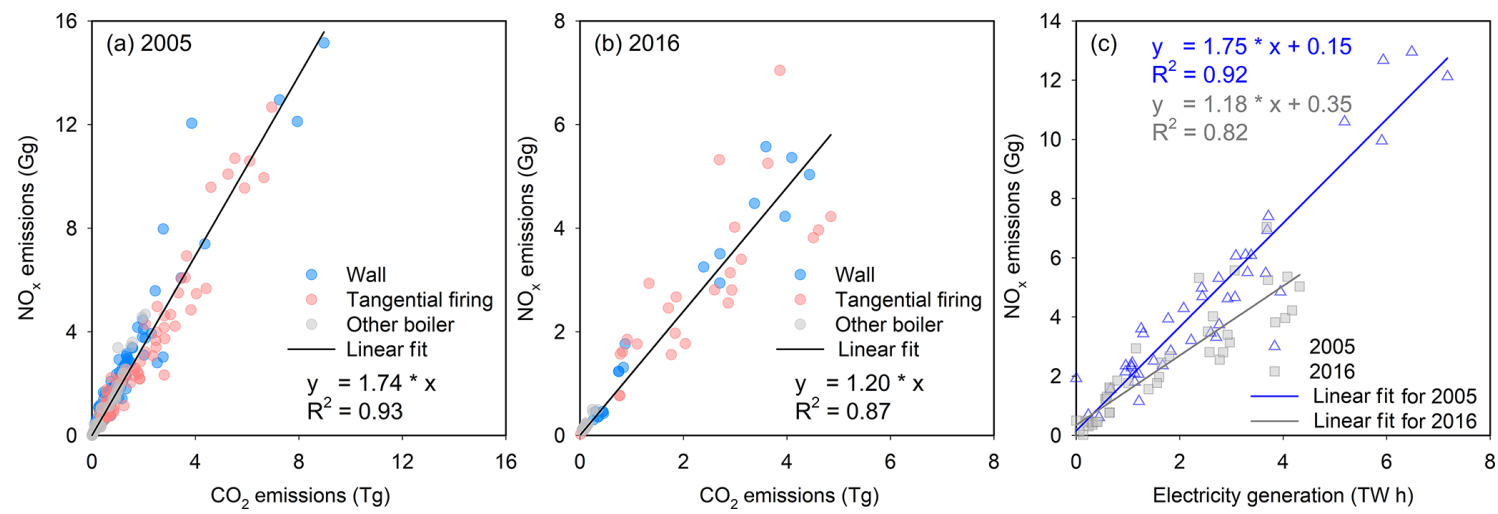

Figure 4. Scatterplots of $E_{\mathrm{NO}_{x}}^{\mathrm{CEMS}}$ versus $E_{\mathrm{CO}_{2}}^{\mathrm{CEMS}}$ for all the US bituminous coal-fired electric generating units for (a) 2005 and (b) 2016. Values are color coded by firing type. (c) Scatterplot of $E_{\mathrm{NO}_{x}}^{\mathrm{CEMS}}$ versus electricity generation of the same units for years 2005 (triangle) and 2016 (square). Only plants without post-combustion $\mathrm{NO}_{x}$ control devices within a given year are used. The electricity generation data are also from eGRID. The lines in all three panels represent the computed linear regressions.

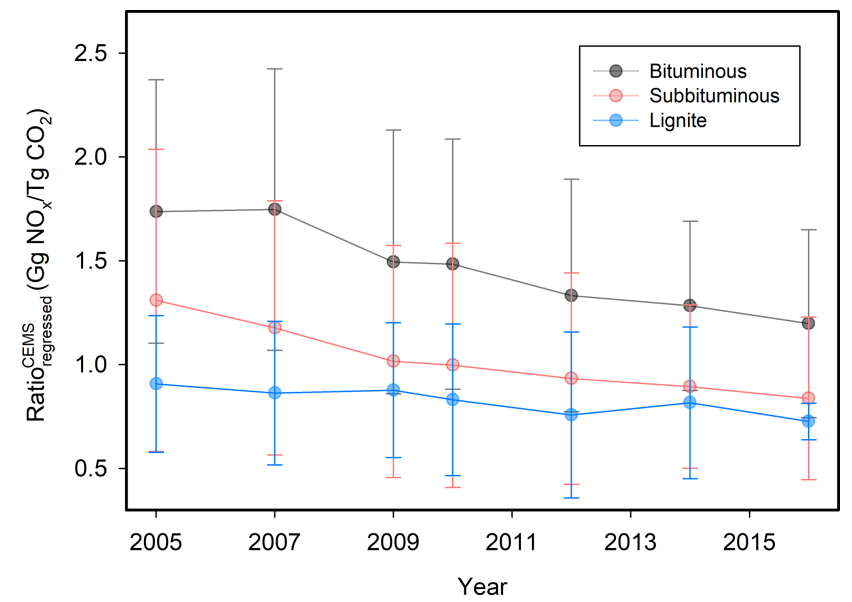

Figure 5. Interannual trends of ratio ${ }_{\text {regressed }}^{\text {CEMS }}$ for power plants using bituminous, subbituminous, and lignite coal types and without post-combustion $\mathrm{NO}_{x}$ control devices in a given year. Error bars show the standard deviations for ratios of $E_{\mathrm{NO}_{x}}^{\mathrm{CEMS}}$ to $E_{\mathrm{CO}_{2}}^{\mathrm{CEMS}}$ for individual power plants.

the unabated emissions per electricity generation, $e_{\text {unabated }}$, which is the emission factor before the flue gas enters the post-combustion control system:

$f_{y}=\frac{e_{\text {unabated }, y}-e_{\text {CEMS }, y}}{e_{\text {unabated }, y}}$,

where $e_{\text {CEMS }}$ denotes the actual emission factor in terms of CEMS $\mathrm{NO}_{x}$ emissions per net electricity generation $\left(\mathrm{Gg} \mathrm{TW} \mathrm{h}^{-1}\right)$.

$e_{\text {unabated }}$ for a given year, $e_{\text {unabated, } y}$, is estimated based on the emission per electricity generation for years prior, $p$, to the installation of the post-combustion control system,

$e_{\text {unabated, } p}$ :

$e_{\text {unabated, } y}=k_{y} \times e_{\text {unabated, } p}$, where the scaling factor, $k_{y}$, is used to account for the change over time in $e_{\text {unabated }}$ associated with improvements in boiler operations discussed in Sect. 2.2.1. $k_{y}$ is calculated as the ratio of the averaged $e_{\text {unabated }}$ (i.e., the slope of the regression of $\mathrm{NO}_{x}$ emissions on electricity generation) in year $t$ to that in year $p$.

To assess the reliability of ratio ${ }^{\text {CEMS-estimated }}$, we selected all power plants that had post-combustion devices installed between 2005 and 2016. Figure 6 shows a scatterplot of ratio $^{\text {CEMS }}$ (i.e., the ratio of $E_{\mathrm{NO}}^{\mathrm{CEMS}}$ to $E_{\mathrm{CO}_{2}}^{\mathrm{CEMS}}$ for individ-

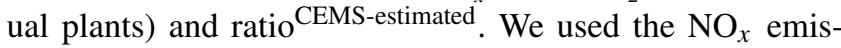
sions factor in $2005, e_{\text {unabated,2005, to predict the unabated }}$

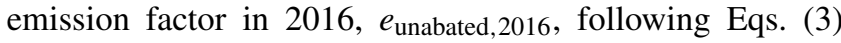
and (4) in order to quantify the removal efficiencies for 2016, $f_{2016}$. The ratio ${ }_{2016}^{\text {CEMS-estimated }}$ value is based on the estimated $f_{2016}$ and ratio ${ }_{\text {regressed,2016 }}$ from Sect. 2.2.1. ratio ${ }^{C E M S}$ and ratio ${ }^{\text {CEMS-estimated }}$ show good correlation $\left(R^{2}=0.64\right)$, which increases our confidence that the estimated removal efficiencies approximate the actual efficiencies. The slight underestimation suggested by the slope of 0.85 arises from uncertainties in estimating unabated $\mathrm{NO}_{x}$ emission factors $\left(e_{\text {unabated }, y}\right)$ using Eq. (4) and thus removal efficiencies $(f)$, which is a major source of error of $E_{\mathrm{CO}_{2}}^{\mathrm{Sat}}$ for power plants that install post-combustion $\mathrm{NO}_{x}$ control systems (see details in Sect. 3.2).

\section{Results and discussion}

In Sect. 3.1, we present $E_{\mathrm{CO}_{2}}^{\mathrm{Sat}}$ for our eight selected power plants and, in Sect. 3.2, we discuss the uncertainties associated with $E_{\mathrm{CO}_{2}}^{\mathrm{Sat}}$. In Sect. 3.3, we compare the US ratios derived in this study with those from a bottom-up inventory for other regions to explore the potential of applying our method to regions outside the US. We finally apply our approach to one power plant in South Africa, which has several inde- 
Table 2. Summary of effective $\mathrm{NO}_{x}$ lifetimes, satellite-derived $\mathrm{NO}_{x}$ emissions $\left(E_{\mathrm{NO}_{x}}^{\mathrm{Sat}}\right)$ and $\mathrm{CO}_{2}$ emissions $\left(E_{\mathrm{CO}_{2}}^{\mathrm{Sat}}\right)$, bottom-up $\mathrm{NO}_{x}$ emissions $\left(E_{\mathrm{NO}_{x}}^{\mathrm{CEMS}}\right.$ ), and $\mathrm{CO}_{2}$ emissions $\left(E_{\mathrm{CO}_{2}}^{\mathrm{CEMS}}\right.$ ) for eight US power plants during May to September from 2005 to 2017 . The 3-year periods are represented by the middle year with an asterisk.

\begin{tabular}{|c|c|c|c|c|c|c|c|c|c|}
\hline Category & Year & $\begin{array}{l}\text { Four Corners } \\
\text { and San Juan }\end{array}$ & Independence & Intermountain & $\begin{array}{r}\text { Martin } \\
\text { Lake }\end{array}$ & Monticello & Navajo & Rockport & $\begin{array}{l}\text { White } \\
\text { Bluff }\end{array}$ \\
\hline $\mathrm{NO}_{x}$ lifetime & $2005-2017$ & 2.7 & 2.5 & 2.2 & 2.3 & 3.2 & 2.3 & 2.4 & 4.3 \\
\hline \multirow{11}{*}{$\begin{array}{l}E_{\mathrm{NO}_{x}}^{\mathrm{Sat}} \\
\left(\mathrm{Mg} \mathrm{h}^{-1}\right)\end{array}$} & $2006^{*}$ & 10.5 & 2.0 & 4.0 & 2.4 & 1.1 & 4.6 & 2.9 & 1.0 \\
\hline & $2007^{*}$ & 10.0 & 1.7 & 4.1 & 2.3 & 1.1 & 4.4 & 3.0 & 0.9 \\
\hline & $2008^{*}$ & 9.4 & 1.6 & 3.7 & 2.0 & 0.8 & 4.5 & 2.6 & 0.9 \\
\hline & $2009^{*}$ & 7.2 & 1.2 & 3.9 & 2.1 & 0.7 & 3.9 & 2.7 & 0.7 \\
\hline & $2010^{*}$ & 6.8 & 1.0 & 4.4 & 2.1 & 0.6 & 3.6 & 2.5 & 0.9 \\
\hline & $2011^{*}$ & 6.5 & 0.9 & 3.6 & 1.8 & 0.7 & 2.5 & 2.5 & 0.8 \\
\hline & $2012^{*}$ & 6.3 & 0.9 & 3.4 & 1.6 & 0.6 & 2.3 & 2.7 & 0.8 \\
\hline & $2013^{*}$ & 5.6 & 0.8 & 3.5 & 1.8 & 0.5 & 1.9 & 2.5 & 0.6 \\
\hline & $2014^{*}$ & 4.4 & 0.7 & 3.5 & 1.7 & 0.8 & 2.2 & 2.3 & 0.5 \\
\hline & $2015^{*}$ & 3.8 & 0.8 & 3.0 & 1.4 & 0.7 & 2.1 & 1.4 & 0.4 \\
\hline & $2016^{*}$ & 3.5 & 1.2 & 1.7 & 1.2 & 0.6 & 2.5 & 1.5 & 0.7 \\
\hline \multirow{11}{*}{$\begin{array}{l}E_{\mathrm{NO}_{x}}^{\mathrm{CEMS}} \\
\left(\mathrm{Mg} \mathrm{h}^{-1}\right)\end{array}$} & $2006^{*}$ & 7.4 & 1.8 & 3.0 & 1.8 & 1.5 & 3.8 & 2.0 & 1.7 \\
\hline & $2007^{*}$ & 7.3 & 1.8 & 3.1 & 1.8 & 1.4 & 3.9 & 2.1 & 1.6 \\
\hline & $2008^{*}$ & 6.8 & 1.8 & 2.9 & 1.8 & 1.3 & 3.8 & 2.0 & 1.6 \\
\hline & $2009^{*}$ & 6.5 & 1.6 & 2.9 & 1.8 & 1.2 & 3.4 & 2.1 & 1.8 \\
\hline & $2010^{*}$ & 6.2 & 1.6 & 2.8 & 1.7 & 1.1 & 2.8 & 2.1 & 1.8 \\
\hline & $2011^{*}$ & 6.2 & 1.4 & 2.5 & 1.5 & 1.0 & 2.2 & 2.2 & 1.9 \\
\hline & $2012^{*}$ & 6.1 & 1.3 & 2.4 & 1.4 & 0.9 & 1.9 & 2.1 & 1.9 \\
\hline & $2013^{*}$ & 5.6 & 1.3 & 2.4 & 1.3 & 0.9 & 1.9 & 2.0 & 2.0 \\
\hline & $2014^{*}$ & 5.2 & 1.2 & 2.5 & 1.3 & 0.8 & 1.9 & 1.9 & 1.9 \\
\hline & $2015^{*}$ & 4.3 & 1.2 & 2.0 & 1.3 & 0.8 & 1.7 & 1.8 & 1.5 \\
\hline & $2016^{*}$ & 3.9 & 1.1 & 1.5 & 1.2 & 0.8 & 1.6 & 1.6 & 1.2 \\
\hline $\begin{array}{l}\left(E_{\mathrm{NO}_{x}}^{\mathrm{Sat}}-E_{\mathrm{NO}_{x}}^{\mathrm{CEMS}}\right) / \\
E_{\mathrm{NO}_{x}}^{\mathrm{CEMS}}\end{array}$ & $2005-2017$ & $10 \%$ & $-22 \%$ & $38 \%$ & $20 \%$ & $-29 \%$ & $21 \%$ & $20 \%$ & $-56 \%$ \\
\hline \multirow{11}{*}{$\begin{array}{l}E_{\mathrm{CO}_{2}}^{\mathrm{Sat}} \\
\left(\mathrm{Gg} \mathrm{h}^{-1}\right)\end{array}$} & $2006^{*}$ & 6.1 & 1.6 & 2.3 & 2.7 & 1.2 & 2.6 & 2.3 & 0.8 \\
\hline & $2007^{*}$ & 5.9 & 1.5 & 2.4 & 2.6 & 1.3 & 2.6 & 2.5 & 0.8 \\
\hline & $2008^{*}$ & 5.6 & 1.4 & 2.3 & 2.3 & 1.1 & 2.8 & 2.4 & 0.8 \\
\hline & $2009^{*}$ & 4.1 & 1.1 & 2.6 & 2.4 & 1.0 & 2.5 & 2.6 & 0.6 \\
\hline & $2010^{*}$ & 3.7 & 1.0 & 3.0 & 2.5 & 0.9 & 2.5 & 2.5 & 0.9 \\
\hline & $2011^{*}$ & 3.4 & 1.0 & 2.6 & 2.2 & 1.0 & 1.7 & 2.5 & 0.8 \\
\hline & $2012^{*}$ & 3.3 & 1.0 & 2.5 & 2.1 & 1.0 & 1.7 & 2.9 & 0.9 \\
\hline & $2013^{*}$ & 3.1 & 0.9 & 2.6 & 2.3 & 0.8 & 1.5 & 2.7 & 0.6 \\
\hline & $2014^{*}$ & 2.5 & 0.8 & 2.8 & 2.2 & 1.2 & 1.8 & 2.6 & 0.6 \\
\hline & $2015^{*}$ & 2.3 & 0.9 & 2.4 & 1.8 & 1.1 & 1.7 & 1.7 & 0.5 \\
\hline & $2016^{*}$ & 2.2 & 1.4 & 1.4 & 1.6 & 1.0 & 2.0 & 1.7 & 0.8 \\
\hline \multirow{11}{*}{$\begin{array}{l}E_{\mathrm{CO}_{2}}^{\mathrm{CEMS}} \\
\left(\mathrm{Gg} \mathrm{h}^{-1}\right)\end{array}$} & $2006^{*}$ & 3.1 & 1.5 & 1.7 & 2.4 & 1.9 & 2.2 & 1.8 & 1.2 \\
\hline & $2007^{*}$ & 3.1 & 1.5 & 1.7 & 2.4 & 1.8 & 2.2 & 1.9 & 1.2 \\
\hline & $2008^{*}$ & 3.0 & 1.5 & 1.6 & 2.4 & 1.8 & 2.2 & 1.8 & 1.2 \\
\hline & $2009^{*}$ & 3.1 & 1.4 & 1.5 & 2.3 & 1.7 & 2.1 & 1.9 & 1.3 \\
\hline & $2010^{*}$ & 3.0 & 1.4 & 1.4 & 2.2 & 1.7 & 2.1 & 1.9 & 1.4 \\
\hline & $2011^{*}$ & 3.0 & 1.3 & 1.3 & 2.1 & 1.5 & 2.0 & 2.0 & 1.4 \\
\hline & $2012^{*}$ & 3.0 & 1.3 & 1.3 & 2.0 & 1.5 & 1.9 & 1.9 & 1.4 \\
\hline & $2013^{*}$ & 2.8 & 1.3 & 1.3 & 1.9 & 1.3 & 1.9 & 1.9 & 1.4 \\
\hline & $2014^{*}$ & 2.6 & 1.1 & 1.4 & 1.9 & 1.3 & 2.0 & 1.8 & 1.3 \\
\hline & $2015^{*}$ & 2.4 & 1.1 & 1.2 & 1.8 & 1.2 & 1.8 & 1.7 & 1.1 \\
\hline & $2016^{*}$ & 2.2 & 1.0 & 1.0 & 1.7 & 1.2 & 1.7 & 1.5 & 0.9 \\
\hline $\begin{array}{l}\left(E_{\mathrm{CO}_{2}}^{\mathrm{Sat}}-E_{\mathrm{CO}_{2}}^{\mathrm{CEMS}}\right) / \\
E_{\mathrm{CO}_{2}}^{\mathrm{CEMS}}\end{array}$ & $2005-2017$ & $33 \%$ & $-12 \%$ & $75 \%$ & $7 \%$ & $-30 \%$ & $4 \%$ & $31 \%$ & $-41 \%$ \\
\hline
\end{tabular}




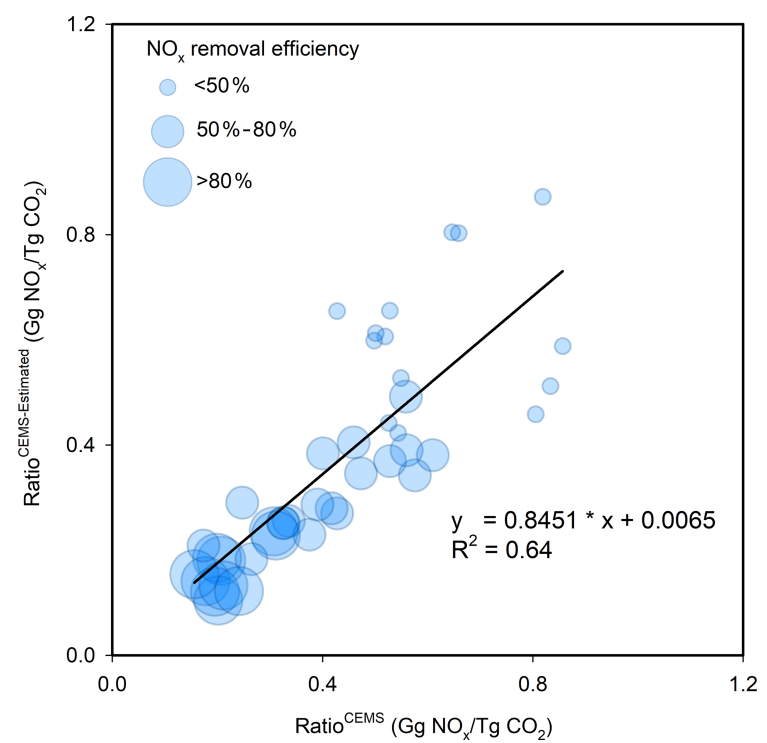

Figure 6. Scatterplot of ratio ${ }^{\text {CEMS-estimated as compared to }}$ ratio ${ }^{\text {CEMS }}$ for 2016. All 44 coal-fired power plants that operated post-combustion devices after 2005 and before 2016 (including 2016) are used in the plot. The sizes of the circles denote the magnitude of the $\mathrm{NO}_{x}$ reduction efficiency of post-combustion control devices estimated in this study. The line represents the linear regres-

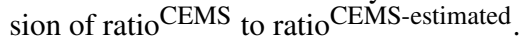

pendent estimates for its $\mathrm{CO}_{2}$ emissions as presented in the scientific literature. Table 2 shows 3-year means of $E_{\mathrm{NO}_{2}}^{\mathrm{Sat}}$, $E_{\mathrm{NO}_{2}}^{\mathrm{CEMS}}, E_{\mathrm{CO}_{2}}^{\mathrm{Sat}}$, and $E_{\mathrm{CO}_{2}}^{\mathrm{CEMS}}$ for eight power plants (Fig. 1). Table 3 lists the mean and the standard deviation of the relative differences between $E_{\mathrm{NO}_{x}}^{\mathrm{CEMS}}$ and $E_{\mathrm{NO}_{x}}^{\mathrm{Sat}}$, and $E_{\mathrm{CO}_{2}}^{\mathrm{CEMS}}$, and $E_{\mathrm{CO}_{2}}^{\mathrm{Sat}}$ for all eight power plants.

\subsection{Satellite-derived $\mathrm{CO}_{2}$ emissions $\left(E_{\mathrm{CO}_{2}}^{\mathrm{Sat}}\right)$}

Figure 7a is a scatterplot of $E_{\mathrm{CO}_{2}}^{\mathrm{Sat}}$ and $E_{\mathrm{CO}_{2}}^{\mathrm{CEMS}}$ for the eight power plants (Fig. 1), seven of which did not have postcombustion $\mathrm{NO}_{x}$ control systems installed during the study period, 2005-2017. The comparison shows a good correlation, $R^{2}$, of 0.66 . The average $E_{\mathrm{CO}_{2}}^{\mathrm{CEMS}}$ for all power plants is $2.0 \mathrm{Gg} \mathrm{h}^{-1}$ and the average $E_{\mathrm{CO}_{2}}^{\mathrm{Sat}}$ is $1.8 \mathrm{Gg} \mathrm{h}^{-1}$. The relative difference for individual 3-year means (defined as $\left(E_{\mathrm{CO}_{2}}^{\mathrm{Sat}}-\right.$ $\left.E_{\mathrm{CO}_{2}}^{\mathrm{CEMS}}\right) / E_{\mathrm{CO}_{2}}^{\mathrm{CEMS}}$ ) is $8 \% \pm 41 \%$ (mean \pm standard deviation). For example, Fig. 3 shows $E_{\mathrm{CO}_{2}}^{\mathrm{Sat}}$ for the Rockport power plant, which typically has a positive bias as compared to $E_{\mathrm{CO}_{2}}^{\mathrm{CEMS}}$ because of a positive bias in $E_{\mathrm{NO}_{x}}^{\mathrm{Sat}}$.

Figure $7 \mathrm{~b}$ presents the generally consistent time series between $E_{\mathrm{CO}_{2}}^{\mathrm{Sat}}$ and $E_{\mathrm{CO}_{2}}^{\mathrm{CEMS}}$, with their annual averages for the eight power plants exhibiting a declining trend of $5 \% \mathrm{yr}^{-1}$ and $3 \% \mathrm{yr}^{-1}$ from $2006^{*}$ to $2016^{*}$ for $E_{\mathrm{CO}_{2}}^{\mathrm{Sat}}$ and $E_{\mathrm{CO}_{2}}^{\mathrm{CEMS}}$, respectively. The reduction in net electricity generation is the driving force underlying the emission changes, which de- creased by $37 \%$ for the eight power plants from 2005 to 2016, as power producers shut down coal-fired units in favor of cheaper and more flexible natural gas as well as solar and wind (USEIA, 2018). It is interesting to note that the temporal variations in $E_{\mathrm{CO}_{2}}^{\mathrm{Sat}}$ are not as "smooth" as those in $E_{\mathrm{CO}_{2}}^{\mathrm{CEMS}}$, which results from fluctuations in $E_{\mathrm{NO}_{x}}^{\mathrm{Sat}}$. Such fluctuations are caused by uncertainties associated with $E_{\mathrm{NO}_{x}}^{\mathrm{Sat}}$, as discussed in Sect. 3.2. For example, changes in VCDs do not necessarily relate linearly with $\mathrm{NO}_{x}$ emissions (e.g., Fig. 2 in Duncan et al., 2013) because of temporal variations in meteorology, and nonlinear $\mathrm{NO}_{x}$ chemistry (Valin et al., 2013) and transport. Averaging VCDs for a long-term period (3 years in this study) helps reduce those influences, but small fluctuations may still exist.

\subsection{Uncertainties}

We estimated the uncertainty of $E_{\mathrm{CO}_{2}}^{\mathrm{Sat}}$ based on the fit performance of $E_{\mathrm{NO}_{x}}^{\mathrm{Sat}}$ and comparison with $E_{\mathrm{CO}_{2}}^{\mathrm{CEMS}}$. The major sources of uncertainty are (a) $E_{\mathrm{NO}_{x}}^{\mathrm{Sat}}$ (Liu et al., 2016), (b) ratio ${ }_{\text {regressed }}^{\mathrm{CEMS}}$, and (c) $f$. We give the estimated uncertainties of each source for individual power plants in Table S2.

\subsection{1 $E_{\mathrm{NO}_{x}}^{\mathrm{Sat}}$}

The uncertainty of $E_{\mathrm{NO}_{x}}^{\mathrm{Sat}}$ is quantified following the method described in Liu et al. (2017), accounting for errors arising from the fit procedure, the $\mathrm{NO}_{x} / \mathrm{NO}_{2}$ ratio, and OMI $\mathrm{NO}_{2}$ VCD observations (Liu et al., 2016). The number 1.32, used for scaling the $\mathrm{NO}_{x} / \mathrm{NO}_{2}$ ratio, is based on assumptions presented in Sect. 6.5.1 of Seinfeld and Pandis (2006) for "typical urban conditions and noontime sun". Note that conditions are quite similar in this study because of the overpass time of OMI close to noon, the selection of cloud-free observations, the focus on the ozone season, and the focus on polluted regions. A case study of chemical transport model (CTM) simulations shows an identical value of 1.32 for Paris in summer (Shaiganfar et al., 2017). The simulated $\mathrm{NO}_{x} / \mathrm{NO}_{2}$ ratio at the OMI overpass time within the boundary layer (up to $2 \mathrm{~km}$ ) in a chemistry-climate model, European Centre for Medium-Range Weather Forecasts - Hamburg (ECHAM)/Modular Earth Submodel System (MESSy) Atmospheric Chemistry (EMAC)(Jöckel et al., 2016), was $1.28 \pm 0.08$ for polluted $\left(\mathrm{NO}_{x}>1 \times 10^{15} \mathrm{molec} \mathrm{cm}^{-2}\right)$ regions for the 1 July 2005 , and $1.32 \pm 0.06$ on average for the ozone season. However, the coarse grid of EMAC $\left(2.8^{\circ} \times 2.8^{\circ}\right.$ in latitude and longitude) may not capture the true range of variation in the $\mathrm{NO}_{x} / \mathrm{NO}_{2}$ ratio. Therefore, we assumed an uncertainty of $20 \%$ arising from the $\mathrm{NO}_{x} / \mathrm{NO}_{2}$ ratio, double the standard deviation of the EMAC ratio.

Additionally, the tropospheric air mass factors (AMFs) used in $\mathrm{NO}_{2}$ retrievals are based on relatively coarsely resolved surface albedo data and a priori $\mathrm{NO}_{2}$ vertical profile shapes, likely causing low-biased VCDs over strong emis- 
Table 3. Summary of relative difference between satellite-derived $\mathrm{NO}_{x}$ emissions $\left(E_{\mathrm{NO}_{x}}^{\mathrm{Sat}}\right)$, bottom-up $\mathrm{NO}_{x}$ emissions $\left(E_{\mathrm{NO}}^{\mathrm{CEMS}}\right)$, satellitederived $\mathrm{CO}_{2}$ emissions $\left(E_{\mathrm{CO}_{2}}^{\mathrm{Sat}}\right.$ ), and bottom-up $\mathrm{CO}_{2}$ emissions $\left(E_{\mathrm{CO}_{2}}^{\mathrm{CEMS}}\right)$ for eight US power plants during May to September from 2005 to 2017. The 3-year periods are represented by the middle year with an asterisk.

\begin{tabular}{lrr|rr}
\hline \multirow{2}{*}{ Year } & \multicolumn{2}{c|}{ Relative difference for $\mathrm{NO}_{x}$} & \multicolumn{2}{|c}{ Relative difference for $\mathrm{CO}_{2}$} \\
\cline { 2 - 5 } & Mean & Standard deviation & Mean & Standard deviation \\
\hline $2006^{*}$ & $15 \%$ & $29 \%$ & $17 \%$ & $39 \%$ \\
$2007^{*}$ & $10 \%$ & $29 \%$ & $16 \%$ & $38 \%$ \\
$2008^{*}$ & $5 \%$ & $30 \%$ & $14 \%$ & $39 \%$ \\
$2009^{*}$ & $-3 \%$ & $34 \%$ & $6 \%$ & $39 \%$ \\
$2010^{*}$ & $-1 \%$ & $38 \%$ & $9 \%$ & $46 \%$ \\
$2011^{*}$ & $-5 \%$ & $31 \%$ & $3 \%$ & $40 \%$ \\
$2012^{*}$ & $-3 \%$ & $31 \%$ & $5 \%$ & $41 \%$ \\
$2013^{*}$ & $-4 \%$ & $38 \%$ & $4 \%$ & $49 \%$ \\
$2014^{*}$ & $-3 \%$ & $36 \%$ & $7 \%$ & $46 \%$ \\
$2015^{*}$ & $-8 \%$ & $35 \%$ & $2 \%$ & $41 \%$ \\
$2016^{*}$ & $-2 \%$ & $29 \%$ & $8 \%$ & $22 \%$ \\
\hline
\end{tabular}
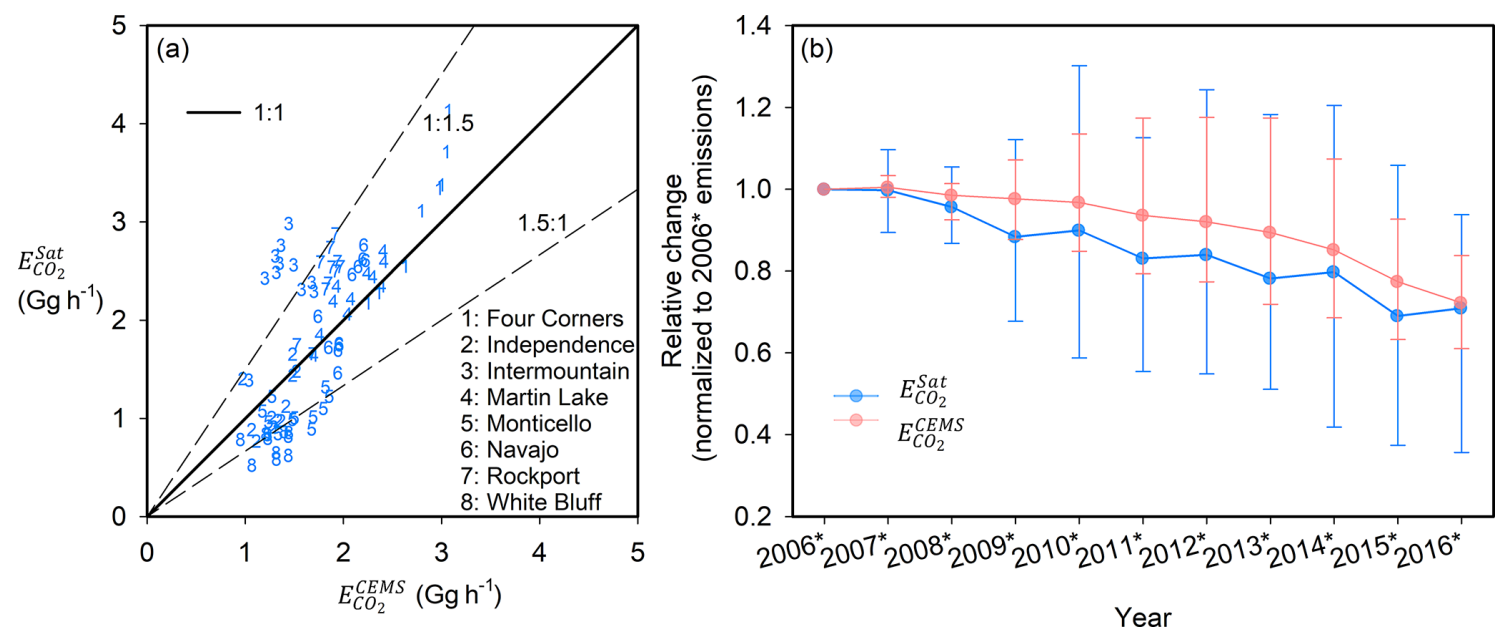

Figure 7. (a) Scatterplot of $E_{\mathrm{CO}_{2}}^{\mathrm{Sat}}$ for eight power plants, as compared to $E_{\mathrm{CO}_{2}}^{\mathrm{CEMS}}$ from $2006^{*}$ to $2016^{*}$. The solid lines represent the ratio of $1: 1$. The dashed lines represent the ratios of $1: 1.5$ and $1.5: 1$, respectively. (b) Interannual trends of the averaged $E_{\mathrm{CO}_{2}}^{\mathrm{Sat}}$ (blue lines) and $E_{\mathrm{CO}_{2}}^{\mathrm{CEMS}}$ (pink lines) are for all power plants analyzed in this study from $2006^{*}$ to $2016^{*}$, as normalized to the $2006^{*}$ value. The whiskers denote the maximum and minimum values.

sion sources (e.g., Russell et al., 2011; McLinden et al., 2014; Griffin et al., 2019). The average AMF uncertainty of 30\% (see Table 2 in Boersma et al., 2007) likely contributes to the underestimation of emissions from some power plants in this study. Both random and systematic (bias) uncertainties in VCDs directly propagate into the uncertainty of $E_{\mathrm{NO}_{x}}^{\mathrm{Sat}}$ (see details in the Supplement of Liu et al., 2016 and Sect. 3.4 of Liu et al., 2017).

The overall uncertainties of $E_{\mathrm{NO}_{x}}^{\mathrm{Sat}}$ range from $57 \%$ to $64 \%$ for all power plants in our analysis, which is comparable with the level of differences between $E_{\mathrm{NO}_{x}}^{\mathrm{Sat}}$ and $E_{\mathrm{NO}}^{\mathrm{CEMS}}$. We expect this uncertainty to be less for new (e.g., TROPOMI) and upcoming (e.g., NASA Tropospheric Emissions: Monitoring Pollution, TEMPO) OMI-like sensors, which have enhanced capabilities relative to OMI. Further details are provided in Sect. S1 of the Supplement.

\subsection{2 ratio regressed}

For power plants without post-combustion devices, ratio ${ }_{\text {regressed }}^{\text {CEMS }}$ derived from the regression (Fig. $4 a$ and $b$ ) and the plant-specific CEMS measurements are within $15 \%$, which is assumed as the uncertainty of the ratio for all power plants.

\subsection{3 $f$}

For power plants with post-combustion devices, an additional uncertainty of $20 \%$ is applied to reflect the difference be- 
tween the predicted and the true removal efficiency as suggested by Fig. 6 .

We assume that their contributions to the overall uncertainty are independent. We then define the total uncertainty, expressed as a $95 \%$ confidence interval, as the sum of the root of the quadratic sum of the aforementioned contribution. The overall uncertainties of $E_{\mathrm{CO}_{2}}^{\mathrm{Sat}}$ are $\sim 60 \%$ for all power plants in our analysis.

\subsubsection{Summary of uncertainties}

However, it is worth noting that this uncertainty estimate is rather conservative. The mean and the standard deviation of the relative differences between $E_{\mathrm{NO}_{x}}^{\mathrm{CEMS}}$ and $E_{\mathrm{NO}_{x}}^{\mathrm{Sat}}$, and $E_{\mathrm{CO}_{2}}^{\mathrm{CEMS}}$ and $E_{\mathrm{CO}_{2}}^{\mathrm{Sat}}$ for all eight power plants provide a good alternative measure of uncertainties (Table 3). The relative differences are rather small, which are $0 \% \pm 33 \%$ and $8 \% \pm 41 \%$ (mean \pm standard deviation) for $\mathrm{NO}_{x}$ and $\mathrm{CO}_{2}$, respectively. We additionally calculate the geometric standard deviations (GSDs) of the difference between $E_{\mathrm{CO}_{2}}^{\mathrm{CEMS}}$ and $E_{\mathrm{CO}_{2}}^{\mathrm{Sat}}$ from $2006^{*}$ to $2016^{*}$ for individual power plants in Table S2. The small values of GSDs ranging from 1.07 to 1.31 further improve our confidence in the accuracy of the derived emissions in this study.

\subsection{Application}

In this section, we assess the feasibility of applying our method to infer $\mathrm{CO}_{2}$ emissions $\left(E_{\mathrm{CO}_{2}}^{\mathrm{Sat}}\right)$ for power plants outside the US. We first compare the $\mathrm{NO}_{x}$ to $\mathrm{CO}_{2}$ emission ratios derived from this study with those from a bottom-up emission database in Sect. 3.3.1. We then apply the US ratio to a power plant in South Africa in Sect. 3.3.2.

\subsubsection{Comparison with bottom-up ratios}

Figure 8 shows the $\mathrm{NO}_{x}$ to $\mathrm{CO}_{2}$ emission ratios for 2010 from the global power emissions database (GPED; Tong et al., 2018a), which is the only publicly available bottom-up emission database that reports both $\mathrm{NO}_{x}$ and $\mathrm{CO}_{2}$ emissions for individual power plants for every country. All countries with over 30 coal-fired power plants in the GPED are shown in Fig. 8. Not surprisingly, countries with more strict standards in place for $\mathrm{NO}_{x}$ emissions from power plants (i.e., $\mathrm{NO}_{x}$ emission limit value, $\mathrm{ELV},<200 \mathrm{mg} \mathrm{m}^{-3}$; hereafter referred to as "more strict countries") have smaller $\mathrm{NO}_{x}$ to $\mathrm{CO}_{2}$ ratios (i.e., 1.0 versus 2.5 on average) than countries with less strict standards (i.e., $\mathrm{NO}_{x} \mathrm{ELV}>200 \mathrm{mg} \mathrm{m}^{-3}$; hereafter referred to as "less strict countries"). Additionally, the correlation coefficients are smaller for more strict countries (i.e., 0.82 on average) as compared to less strict countries (i.e., 0.96 on average) because power plants in more strict countries are more likely to have installed post-combustion $\mathrm{NO}_{x}$ control systems, which likely lowered ratio ${ }_{y}^{\mathrm{CEMS}}$, sim-

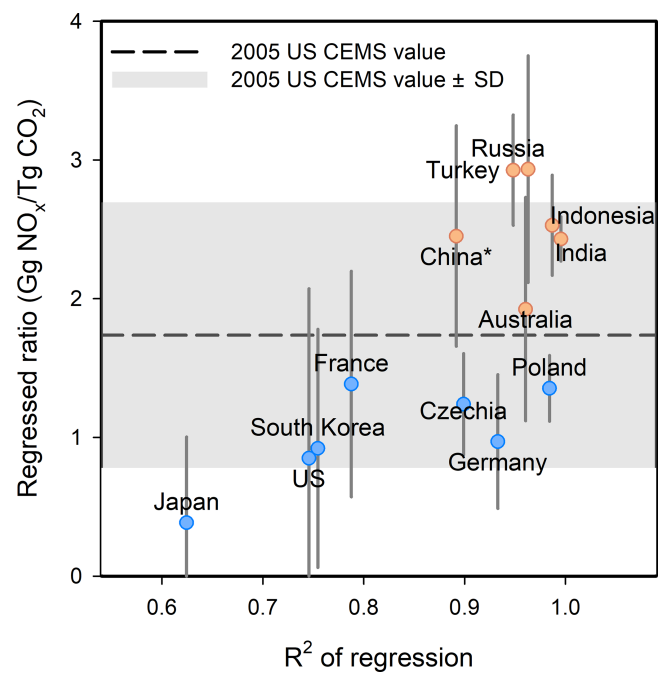

Figure 8. Comparison of the regressed $\mathrm{NO}_{x}$ to $\mathrm{CO}_{2}$ emission ratios derived from the global power emissions database (GPED) for different regions versus the correlation coefficient of the regression. The blue and red circles denote regions that are subject to more strict standards for $\mathrm{NO}_{x}$ emissions from power plants (i.e., a $\mathrm{NO}_{x} \mathrm{ELV}$ of $200 \mathrm{mg} \mathrm{m}^{-3}$ or less) and other regions, respectively. The $y$ axis is the slope of the regression of the $\mathrm{NO}_{x}$ to $\mathrm{CO}_{2}$ emissions with an assumed $y$-intercept of zero. Error bars show the standard deviations for the $\mathrm{NO}_{x}$ to $\mathrm{CO}_{2}$ emission ratios for individual power plants. The $x$ axis is correlation coefficient of the regression. The dashed line represents 2005 US ratio ${ }_{\text {regressed }}^{\text {CEMS }}$ for bituminous coal derived in this study. The grey shadow represents 2005 US ratio regressed $^{\text {CEMS }} \pm$ standard deviation. ${ }^{*}$ China switched from being a less strict country to a more strict country in 2014 , when most coal-fired power plants in China were required to comply with its new emission standards (GB13223-2011).

ilar to what occurred in the US over our analysis period (Sect. 2.2.2).

We further compare the 2005 US ratio ${ }_{\text {regressed }}^{\mathrm{CEMS}}$ in Table 1 with the GPED $\mathrm{NO}_{x}$ to $\mathrm{CO}_{2}$ emission ratios for less strict countries. We chose the 2005 value for comparison based on the following considerations. In 2005, the US EPA issued the Clean Air Interstate Rule (CAIR) to address the interstate transport of ozone and fine particulate matter pollution for eastern US states, which reduced $\mathrm{NO}_{x}$ emissions and thus $\mathrm{NO}_{x}$ to $\mathrm{CO}_{2}$ ratios (ratio ${ }_{y}^{\mathrm{CEMS}}$ ). However, similar comprehensive control strategies have not been adopted in less strict countries. In this way, the 2005 values are expected to show better consistency with the $\mathrm{NO}_{x}$ to $\mathrm{CO}_{2}$ ratios of less strict countries than values for more recent years. Note that the GPED database does not give information on ratios by coal type. Therefore, we use ratio ${ }_{\text {regressed }}^{\text {CEMS }}$ for bituminous coal, which is the most widely used coal type in coal-fired power plants in most countries.

The ratios for individual power plants in less strict coun-

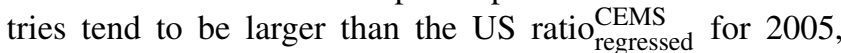
considering that power plants in those countries may not be 
equipped with any $\mathrm{NO}_{x}$ control devices or even low- $\mathrm{NO}_{x}$ burners, a technology which is widely installed in US power plants with and without post-combustion $\mathrm{NO}_{x}$ control devices. Most ratios range from US 2005 ratio $_{\text {regressed }}^{\text {CEMS }} 2005$ ratio $_{\text {regressed }}^{\text {CEMS }}+$ standard deviation (Fig. 8). It is no surprise that some less strict countries have ratios higher than this range, which also occurs for some US power plants without post-combustion emission controls (Fig. 4). However, there are considerable uncertainties in the GPED database given the scarcity of reliable emissions information in less strict countries. For example, the GPED $\mathrm{NO}_{x}$ and $\mathrm{CO}_{2}$ emissions estimates for Turkey and Russia, which are outliers in Fig. 8, are subject to more assumptions and thus larger uncertainties than countries with high-quality country-specific emission data, such as China, which has a high-resolution emissions database (CPED; Liu et al., 2015), and India, which has a database developed by Argonne National Laboratory (Lu et al., 2012).

Figure 9 shows a schematic of our methodology to estimate the $\mathrm{NO}_{x}$ to $\mathrm{CO}_{2}$ emission ratios for power plants outside the US. We adopt different approaches for more and less strict countries. More strict countries, including Canada, European Union (EU) member states, Japan, South Korea, and, more recently, China, usually use CEMS to monitor emissions, particularly from the largest emitters. For power plants with CEMS measurements for both $\mathrm{NO}_{x}$ and $\mathrm{CO}_{2}$ emissions, it is straightforward to use the measured ratios. However, there is still a significant number of power plants in those countries without CEMS technology, particularly for $\mathrm{CO}_{2}$ measurements. For example, EU member states do not require power plants to use CEMS for $\mathrm{CO}_{2}$ reporting and the majority of plants in the EU therefore reports $\mathrm{CO}_{2}$ emissions based on emission factors (Sloss, 2011). Therefore, we recommend applying our method described in Sect. 2.2 to infer region-specific ratios for those power plants. The US ratio ${ }_{\text {regressed }}^{\text {CEMS }}$ could be a less accurate but reasonable approximation when no CEMS data are available, considering those countries share $\mathrm{NO}_{x}$ ELVs for power plants that are similar to the US. For less strict countries, we recommend using the 2005 US values by coal type when ratios from countries with similar $\mathrm{NO}_{x}$ emission standards are not available. We also recommend assigning a range from 2005 ratio regressed $_{\text {CEMS }}^{\text {CEM }}$ to $2005 \mathrm{ratio}_{\text {regressed }}^{\mathrm{CEMS}}+$ standard deviation, instead of a fixed value, to the ratio for inferring $\mathrm{CO}_{2}$ emissions, considering the knowledge about ratios from those regions is too low to narrow the constraint.

As demonstrated in Sect. 2.2, our method presented in this study provides a reasonable estimate of the ratio for power plants without post-combustion $\mathrm{NO}_{x}$ control devices with only knowing coal type. Even for regions without reliable emission information, the information on coal type, particularly for large power plants, are very likely publicly available. For power plants that install post-combustion $\mathrm{NO}_{x}$ control technology, we additionally require the removal efficiency of the device to derive the ratio. The removal efficiency of postcombustion $\mathrm{NO}_{x}$ control devices is usually directly reported, as the operation of such devices is very expensive and is expected to be subject to strict quality control and assurance standards. In contrast to bottom-up approaches, many details are required for calculating $\mathrm{NO}_{x}$ and $\mathrm{CO}_{2}$ emissions, including coal type, coal quality, boiler firing type, $\mathrm{NO}_{x}$ emission control device type, and operating condition of boiler and emission control device.

\subsubsection{Application to Matimba power plant in South Africa}

We apply the methodology shown in Fig. 9 to estimate $\mathrm{CO}_{2}$ emissions from a South African power plant, Matimba, which is a strong isolated $\mathrm{NO}_{x}$ point source (Fig. 10). It is a well-studied power plant, having had its emissions estimated using several different methods as reported in the literature. We estimate $E_{\mathrm{NO}_{x}}^{\mathrm{Sat}}$ for Matimba from 2005 to 2017 based on $\mathrm{OMI} \mathrm{NO}_{2}$ observations following the approach in Sect. 2.1. Matimba uses subbituminous coal with a calorific value of $\sim 20 \mathrm{MJ} \mathrm{kg}^{-1}$ (Makgato and Chirwa, 2017). We apply the ratio ranging from 2005 ratio regressed $^{\text {CEMS }} 2005$ ratio $_{\text {regressed }}^{\text {CEMS }}+$ standard deviation to Matimba, following the methodology in Fig. 9, considering that South Africa is a less strict country without any post-combustion $\mathrm{NO}_{x}$ control devices (Pretorius et al., 2015). Our derived $E_{\mathrm{CO}_{2}}^{\mathrm{Sat}}$ is shown in Fig. 11 and fluctuates over time. The growth after $2008^{*}$ is most likely caused by the increased unit operating hours driven by the desire to meet fully the demand for electricity in South Africa after a period of rolling blackouts (2007-2008) (Duncan et al., 2016). The decline afterwards may be associated with the tripping of generating units at the Matimba because of overload and shortage of coal as reported by South African government news agency (available at: https://www.sanews.gov.za/south-africa/ eskom-alone-cannot-solve-our-energy-challenges, last access: 1 March 2019). The increase in $2016^{*}$ may be associated with a newly built power plant, Medupi, which began limited operations in 2015. Note that the range of $E_{\mathrm{CO}_{2}}^{\mathrm{Sat}}$ (grey band) in Fig. 11 represents the emissions based on a range of $\mathrm{NO}_{x}$-to- $\mathrm{CO}_{2}$ ratios and not the uncertainty. We calculate the uncertainty of $E_{\mathrm{CO}_{2}}^{\mathrm{Sat}}$ for Matimba following Sect. 3.2 with an additional uncertainty of $\sim 50 \%$ to reflect the fact that the ratio may range from ratio ${ }_{\text {regressed }}^{\mathrm{CEMS}}$ to ratio ${ }_{\text {regressed }}^{\mathrm{CEMS}}+$ standard deviation. The overall uncertainty of $E_{\mathrm{CO}_{2}}^{\mathrm{Sat}}$ for Matimba is $81 \%$, as shown by the error bars in Fig. 11 .

Figure 11 shows $E_{\mathrm{CO}_{2}}^{\mathrm{Sat}}$ derived in this study and other independent estimates reported in the literature, including two top-down (Nassar et al., 2017; Reuter et al., 2019) and three bottom-up estimates (Wheeler and Ummel, 2008; Tong et al., 2018a; Oda et al., 2018). Despite the uncertainties associated with each of these methods, the $\mathrm{CO}_{2}$ emissions estimates agree reasonably well, but we do not have sufficient 


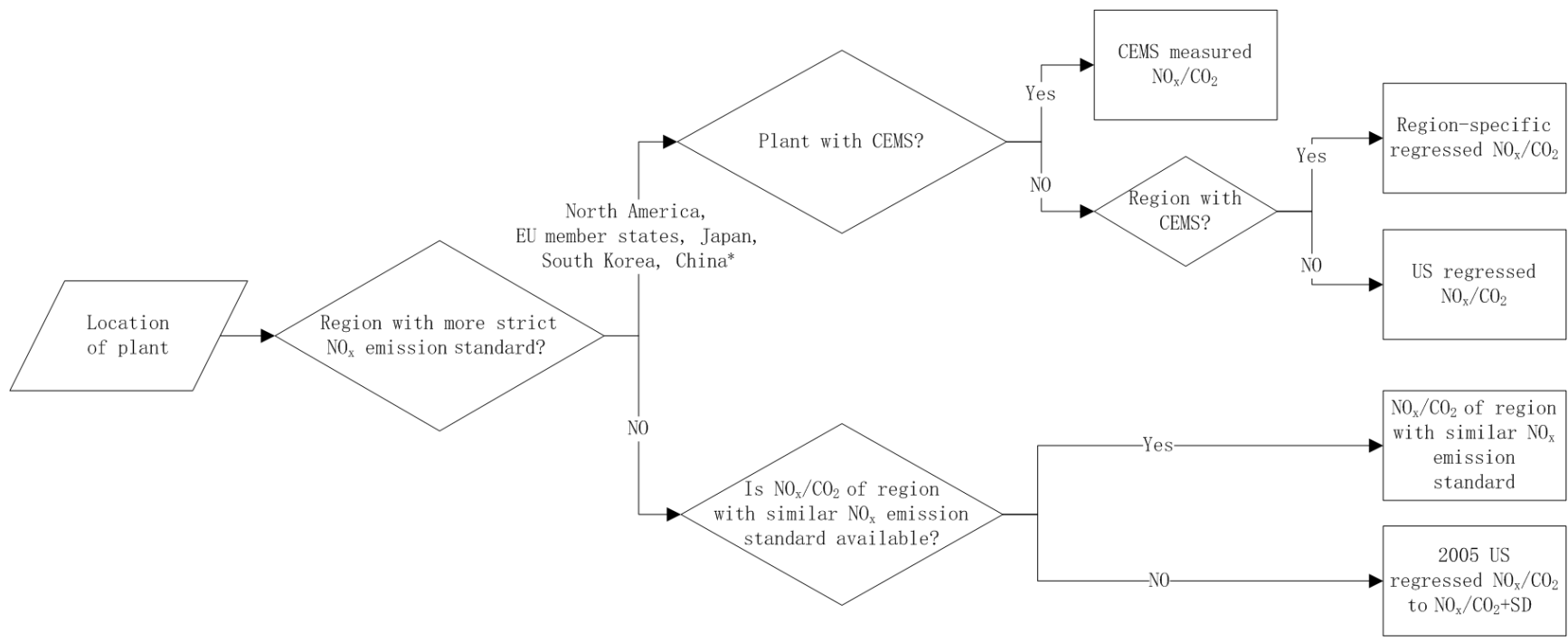

Figure 9. Schematic of our methodology to estimate the $\mathrm{NO}_{x}$ to $\mathrm{CO}_{2}$ emission ratios for power plants outside the US. * China switched from being a less strict country to a more strict country in 2014, when most coal-fired power plants in China were required to comply with its new emission standards (GB13223-2011).

(a) Calm wind

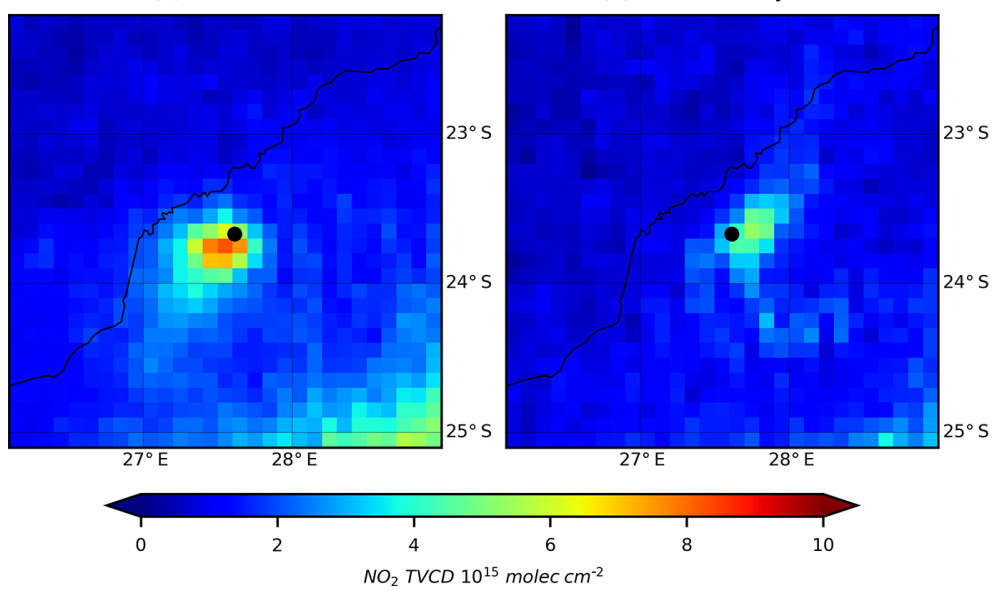

(c) Difference

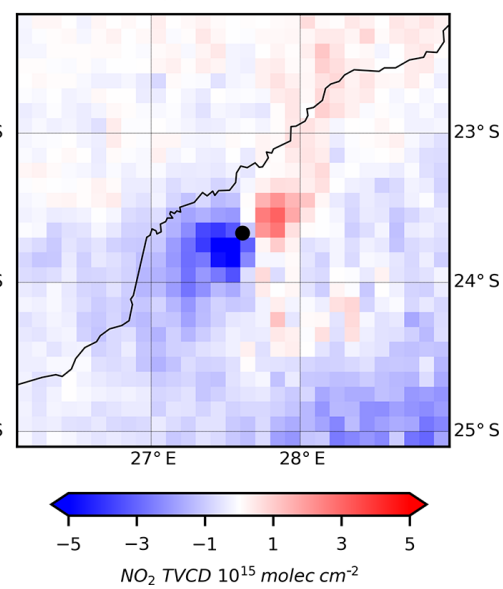

Figure 10. Mean $\mathrm{OMI} \mathrm{NO}_{2}$ tropospheric VCDs around the Matimba power plant (Lephalale, South Africa) for (a) calm, (b) southwesterly wind conditions, and (c) their difference (southwesterly minus calm) for the period of 2005-2017. The location of Matimba is represented by a black dot.

information to understand the differences between these estimates. However, Tong et al. (2018a) present in their CPED database both $\mathrm{CO}_{2}$ and $\mathrm{NO}_{x}$ emissions, which allows us to determine that the difference between $E_{\mathrm{NO}_{x}}^{\mathrm{Sat}}$ and the CPED bottom-up estimate contributes significantly to the difference in $\mathrm{CO}_{2}$ estimates from the two methods. $E_{\mathrm{NO}_{x}}^{\mathrm{Sat}}$ for Matimba is $3.8 \mathrm{Mg} \mathrm{h}^{-1}$ for $2010^{*}$, which is $65 \%$ smaller than the estimate by Tong et al. (2018a) for 2010. It is not surprising to see such differences considering the uncertainties of satellite-derived $\mathrm{NO}_{x}$ emissions and bottom-up estimates for power plants without reliable CEMS measurements. For instance, $E_{\mathrm{NO}_{x}}^{\mathrm{Sat}}$ is potentially underestimated because of the bias in the OMI $\mathrm{NO}_{2}$ standard product (version 3.1) associated with a low-resolution static climatology of surface Lambert-Equivalent Reflectivity (OMLER) (Kleipool et al., 2008). We perform a sensitivity analysis by using the preliminary new version of the $\mathrm{OMI} \mathrm{NO}_{2}$ product, which uses new geometry-dependent Moderate Resolution Imaging Spectroradiometer (MODIS)-based surface reflectivity. The inferred $E_{\mathrm{NO}_{x}}^{\mathrm{Sat}}$ based on the new product is over $10 \%$ higher than version 3.1. The bottom-up estimates for Matimba are subject to significant uncertainties as well. For example, Tong et al. (2018a) used national total fuel consumption of the power sector for South Africa as reported by the International Energy Agency to estimate fuel consumption at the plant level, 


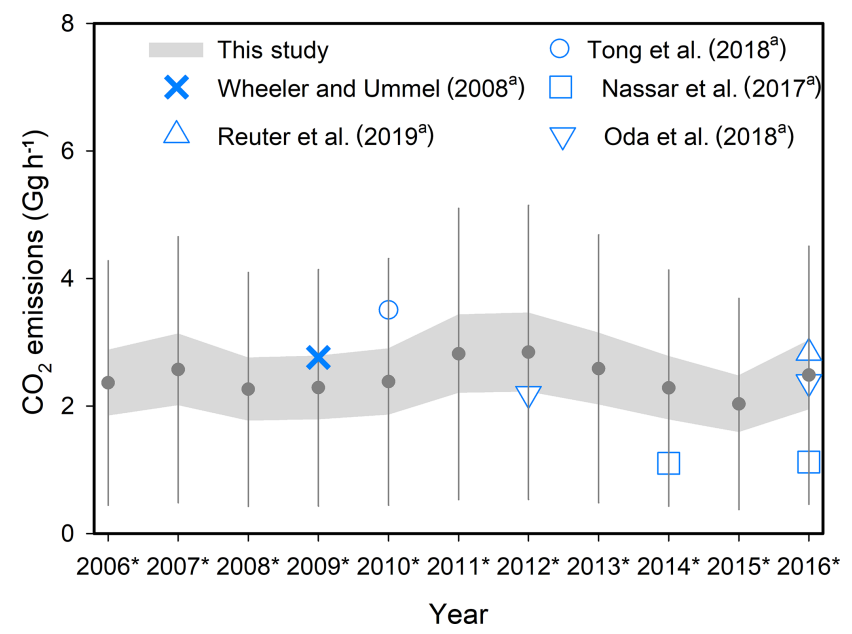

Figure 11. Comparison of $E_{\mathrm{CO}_{2}}^{\mathrm{Sat}}\left(\mathrm{Gg} \mathrm{h}^{-1}\right)$ derived in this study, with existing estimates for the Matimba power plant during 2005 to 2017. $E_{\mathrm{CO}_{2}}^{\mathrm{Sat}}$ is inferred based on the $\mathrm{NO}_{x}$ to $\mathrm{CO}_{2}$ emissions ratio ranging from ratio ${ }_{\text {regressed }}^{\mathrm{CEMS}}$ to ratio ${ }_{\text {regressed }}^{\mathrm{CEMS}}+$ standard deviation of ratio. The upper and lower grey bands denote the emissions inferred from ratio ${ }_{\text {regressed }}^{\text {CEMS }}$ and ratio ${ }_{\text {regressed }}^{\text {CEMS }}+$ standard deviation of ratio, respectively. The grey dots and error bars show the mean of the upper and lower grey bands and their uncertainties, respectively. a Emissions are estimated for 2009 by Wheeler and Ummel (2008), for 2010 by Tong et al. (2018a), for 2014 and 2016 by Nassar et al. (2017), for 2016 by Reuter et al. (2019), and for 2012 and 2016 by Oda et al. (2018).

as detailed fuel consumption for each plant is not currently available. Additionally, they used default $\mathrm{NO}_{x}$ emission factors obtained from the literature because of the absence of country-specific measurement data.

\section{Conclusions}

In our study, we investigated the feasibility of using satellite data of $\mathrm{NO}_{2}$ from power plants to infer co-emitted $\mathrm{CO}_{2}$ emissions, which could serve as complementary verification of bottom-up inventories or be used to supplement these inventories that are highly uncertain in many regions of the world. For example, our estimates will serve as an independent check of $\mathrm{CO}_{2}$ emissions that will be inferred from satellite retrievals of future $\mathrm{CO}_{2}$ sensors (Bovensmann et al., 2010). Currently, uncertainties in $\mathrm{CO}_{2}$ emissions from power plants confound national and international efforts to design effective climate mitigation strategies.

We estimate $\mathrm{NO}_{2}$ and $\mathrm{CO}_{2}$ emissions during the "ozone season" from individual power plants from satellite observations of $\mathrm{NO}_{2}$ and demonstrate its utility for US power plants, which have accurate CEMS with which to evaluate our method. We systematically identify the sources of variation, such as types of coal, boiler, and $\mathrm{NO}_{x}$ emission control device, and change in operating conditions, which affect the
$\mathrm{NO}_{x}$ to $\mathrm{CO}_{2}$ emissions ratio. Understanding the causes of these variations will allow for better-informed assumptions when applying our method to power plants that have no or uncertain information on the factors that affect their emissions ratios. For example, we estimated $\mathrm{CO}_{2}$ emissions from the large and isolated Matimba power plant in South Africa, finding that our emissions estimate shows reasonable agreement with other independent estimates.

We found that it is feasible to infer $\mathrm{CO}_{2}$ emissions from satellite $\mathrm{NO}_{2}$ observations, but limitations of the current satellite data (e.g., spatiotemporal resolution or signal-tonoise) only allow us to apply our method to eight large and isolated U.S. power plants. Looking forward, we anticipate that these limitations will diminish for the recently launched (October 2017) TROPOMI and three upcoming (launches expected in the early 2020s) geostationary instruments (NASA TEMPO, European Space Agency and Copernicus Programme Sentinel-4, Korea Meteorological Administration Geostationary Environment Monitoring Spectrometer, GEMS), which are designed to have superior capabilities to OMI. High-resolution TROPOMI observations are capable of describing the spatiotemporal variability of $\mathrm{NO}_{2}$, even in a relatively small city like Helsinki (Ialongo et al., 2019) and allow estimates of $\mathrm{NO}_{x}$ emissions to be calculated for shorter timeframes (Goldberg et al., 2019c). Higher spatial and temporal resolutions will likely reduce uncertainties in estimates of $\mathrm{NO}_{x}$ emissions as well as allow for the separation of more power plant plumes from nearby sources, thus increasing the number of power plants available for analysis. Therefore, future work will be to apply our method to these new datasets, especially after several years of vetted data become available. Additional future work will include applying our method to other regions of the world with reliable CEMS information, such as Europe, Canada and, more recently, China, to develop a more reliable and complete database with region-specific ratios.

Data availability. The OMI $\mathrm{NO}_{2}$ and MERRA-2 wind data can be downloaded from the Goddard Earth Sciences Data and Information Services Center (GES DISC). The OMI $\mathrm{NO}_{2}$ data are available at https://doi.org/10.5067/Aura/OMI/DATA2017; Krotkov et al. (2018). The MERRA-2 wind data are available at https://doi.org/10.5067/Aura/OMI/DATA2033; Joiner (2018). The CEMS emissions data can be downloaded from Air Markets Program Data (available at https://ampd.epa.gov/ampd/, US EPA, 2017). The GPED data are available at http://www.meicmodel.org/ dataset-gped.html; Tong et al. (2018b).

Supplement. The supplement related to this article is available online at: https://doi.org/10.5194/acp-20-99-2020-supplement.

Author contributions. FL, BND, and NAK designed the framework. FL, SB, LNL, DG, CAM, and DLG developed the $\mathrm{NO}_{x}$ emis- 
sion fitting algorithm and FL carried it out. FL and ZL analyzed the $\mathrm{NO}_{x} / \mathrm{CO}_{2}$ emission ratio. FL and BND prepared the manuscript with contributions from all co-authors.

Competing interests. The authors declare that they have no conflict of interest.

Acknowledgements. The Dutch-Finnish built OMI instrument is part of the NASA EOS Aura satellite payload. KNMI and the Netherlands Space Agency (NSO) manage the OMI project. We thank the US EPA for making the Emissions and Generation Resource Integrated Database (eGRID) available online. We thank the two anonymous reviewers for helpful comments during ACP discussions.

Financial support. This research has been supported by the NASA (Earth Science Division Atmospheric Composition: Modeling and Analysis Program, ACMAP) and the NASA Aura Science team.

Review statement. This paper was edited by Aijun Ding and reviewed by two anonymous referees.

\section{References}

Ackerman, K. V. and Sundquist, E. T.: Comparison of two U.S. power-plant carbon dioxide emissions data sets, Environ. Sci. Technol., 42, 5688-5693, https://doi.org/10.1021/es800221q, 2008.

Basu, S., Guerlet, S., Butz, A., Houweling, S., Hasekamp, O., Aben, I., Krummel, P., Steele, P., Langenfelds, R., Torn, M., Biraud, S., Stephens, B., Andrews, A., and Worthy, D.: Global $\mathrm{CO}_{2}$ fluxes estimated from GOSAT retrievals of total column $\mathrm{CO}_{2}$, Atmos. Chem. Phys., 13, 8695-8717, https://doi.org/10.5194/acp13-8695-2013, 2013.

Beirle, S., Boersma, K. F., Platt, U., Lawrence, M. G., and Wagner, T.: Megacity emissions and lifetimes of nitrogen oxides probed from space, Science, 333, 1737-1739, 2011.

Berezin, E. V., Konovalov, I. B., Ciais, P., Richter, A., Tao, S., Janssens-Maenhout, G., Beekmann, M., and Schulze, E.D.: Multiannual changes of $\mathrm{CO}_{2}$ emissions in China: indirect estimates derived from satellite measurements of tropospheric $\mathrm{NO}_{2}$ columns, Atmos. Chem. Phys., 13, 9415-9438, https://doi.org/10.5194/acp-13-9415-2013, 2013.

Boersma, K. F., Eskes, H. J., Veefkind, J. P., Brinksma, E. J., van der A, R. J., Sneep, M., van den Oord, G. H. J., Levelt, P. F., Stammes, P., Gleason, J. F., and Bucsela, E. J.: Near-real time retrieval of tropospheric $\mathrm{NO}_{2}$ from OMI, Atmos. Chem. Phys., 7, 2103-2118, https://doi.org/10.5194/acp-7-2103-2007, 2007.

Bovensmann, H., Buchwitz, M., Burrows, J. P., Reuter, M., Krings, T., Gerilowski, K., Schneising, O., Heymann, J., Tretner, A., and Erzinger, J.: A remote sensing technique for global monitoring of power plant $\mathrm{CO}_{2}$ emissions from space and related applications,
Atmos. Meas. Tech., 3, 781-811, https://doi.org/10.5194/amt-3781-2010, 2010.

Buchwitz, M., Reuter, M., Schneising, O., Noël, S., Gier, B., Bovensmann, H., Burrows, J. P., Boesch, H., Anand, J., Parker, R. J., Somkuti, P., Detmers, R. G., Hasekamp, O. P., Aben, I., Butz, A., Kuze, A., Suto, H., Yoshida, Y., Crisp, D., and O'Dell, C.: Computation and analysis of atmospheric carbon dioxide annual mean growth rates from satellite observations during 2003-2016, Atmos. Chem. Phys., 18, 17355-17370, https://doi.org/10.5194/acp-18-17355-2018, 2018.

Burrows, J. P., Hölzle, E., Goede, A. P. H., Visser, H., and Fricke, W.: SCIAMACHY - scanning imaging absorption spectrometer for atmospheric chartography, Acta Astronaut., 35, 445-451, https://doi.org/10.1016/0094-5765(94)00278-T, 1995.

Crisp, D.: Measuring atmospheric carbon dioxide from space with the Orbiting Carbon Observatory-2 (OCO-2), Proc. SPIE, 9607 960702, https://doi.org/10.1117/12.2187291, 2015.

de Foy, B., Lu, Z., Streets, D. G., Lamsal, L. N., and Duncan, B. $\mathrm{N}$.: Estimates of power plant $\mathrm{NO}_{x}$ emissions and lifetimes from $\mathrm{OMI} \mathrm{NO}_{2}$ satellite retrievals, Atmos. Environ., 116, 1-11, 2015.

Duncan, B. N., Yoshida, Y., de Foy, B., Lamsal, L. N., Streets, D. G., Lu, Z., Pickering, K. E., and Krotkov, N. A.: The observed response of Ozone Monitoring Instrument (OMI) $\mathrm{NO}_{2}$ columns to $\mathrm{NO}_{x}$ emission controls on power plants in the United States: 2005-2011, Atmos. Environ., 81, 102-111, 2013.

Duncan, B. N., Lamsal, L. N., Thompson, A. M., Yoshida, Y., Lu, Z., Streets, D. G., Hurwitz, M. M., and Pickering, K. E.: A spacebased, high-resolution view of notable changes in urban $\mathrm{NO}_{\mathrm{x}}$ pollution around the world (2005-2014), J. Geophys. Res., 121, 976-996, https://doi.org/10.1002/2015jd024121, 2016.

Fioletov, V. E., McLinden, C. A., Krotkov, N., Moran, M. D., and Yang, K.: Estimation of $\mathrm{SO}_{2}$ emissions using OMI retrievals, Geophys. Res. Lett., 38, L21811, https://doi.org/10.1029/2011gl049402, 2011.

Gelaro, R., McCarty, W., Suárez, M. J., Todling, R., Molod, A., Takacs, L., Randles, C. A., Darmenov, A., Bosilovich, M. G., Reichle, R., Wargan, K., Coy, L., Cullather, R., Draper, C., Akella, S., Buchard, V., Conaty, A., Silva, A. M. d., Gu, W., Kim, G.K., Koster, R., Lucchesi, R., Merkova, D., Nielsen, J. E., Partyka, G., Pawson, S., Putman, W., Rienecker, M., Schubert, S. D., Sienkiewicz, M., and Zhao, B.: The Modern-Era Retrospective Analysis for Research and Applications, Version 2 (MERRA2), J. Climate, 30, 5419-5454, https://doi.org/10.1175/jcli-d-160758.1, 2017.

Glenn, C., Logan, T., Vu, B., Walsh, M., and Williams, P.: Evaluation of $\mathrm{NO}_{\mathrm{x}}$ Flue Gas Analyzers for Accuracy and Their Applicability for Low-Concentration Measurements AU - Gluck, Steven, J. Air Waste Manage., 53, 749-758, https://doi.org/10.1080/10473289.2003.10466208, 2003.

Goldberg, D. L., Saide, P. E., Lamsal, L. N., de Foy, B., Lu, Z., Woo, J.-H., Kim, Y., Kim, J., Gao, M., Carmichael, G., and Streets, D. G.: A top-down assessment using $\mathrm{OMI} \mathrm{NO}_{2}$ suggests an underestimate in the $\mathrm{NO}_{x}$ emissions inventory in Seoul, South Korea, during KORUS-AQ, Atmos. Chem. Phys., 19, 1801-1818, https://doi.org/10.5194/acp-19-1801-2019, 2019a.

Goldberg, D. L., Lu, Z., Oda, T., Lamsal, L. N., Liu, F., Griffin, D., McLinden, C. A., Krotkov, N. A., Duncan, B. N., and Streets, D. G.: Exploiting $\mathrm{OMI} \mathrm{NO}_{2}$ satellite observations to infer fossil-fuel 
$\mathrm{CO}_{2}$ emissions from U.S. megacities, Sci. Total Environ., 695, 133805, https://doi.org/10.1016/j.scitotenv.2019.133805, 2019b. Goldberg, D. L., Lu, Z., Streets, D. G., de Foy, B., Griffin, D., McLinden, C. A., Lamsal, L. N., Krotkov, N. A., and Eskes, H.: Enhanced Capabilities of TROPOMI $\mathrm{NO}_{2}$ : Estimating $\mathrm{NO}_{x}$ from North American Cities and Power Plants, Environ. Sci. Technol., 53, 12594-12601, https://doi.org/10.1021/acs.est.9b04488, 2019c.

Griffin, D., Zhao, X., McLinden, C. A., Boersma, F., Bourassa, A., Dammers, E., Degenstein, D., Eskes, H., Fehr, L., Fioletov, V., Hayden, K., Kharol, S. K., Li, S.-M., Makar, P., Martin, R. V., Mihele, C., Mittermeier, R. L., Krotkov, N., Sneep, M., Lamsal, L. N., Linden, M. t., Geffen, J. v., Veefkind, P., and Wolde, M.: High-resolution mapping of nitrogen dioxide with TROPOMI: First results and validation over the Canadian oil sands, Geophys. Res. Lett., 46, 1049-1060, https://doi.org/10.1029/2018g1081095, 2019.

Hakkarainen, J., Ialongo, I., and Tamminen, J.: Direct spacebased observations of anthropogenic $\mathrm{CO}_{2}$ emission areas from OCO-2, Geophys. Res. Lett., 43, 11400-11406, https://doi.org/10.1002/2016GL070885, 2016.

Hakkarainen, J., Ialongo, I., Maksyutov, S., and Crisp, D.: Analysis of Four Years of Global $\mathrm{XCO}_{2}$ Anomalies as Seen by Orbiting Carbon Observatory-2, Remote Sens., 11, 850, https://doi.org/10.3390/rs11070850, 2019.

Houweling, S., Baker, D., Basu, S., Boesch, H., Butz, A., Chevallier, F., Deng, F., Dlugokencky, E. J., Feng, L., Ganshin, A., Hasekamp, O., Jones, D., Maksyutov, S., Marshall, J., Oda, T., O’Dell, C. W., Oshchepkov, S., Palmer, P. I., Peylin, P., Poussi, Z., Reum, F., Takagi, H., Yoshida, Y., and Zhuravlev, R.: An intercomparison of inverse models for estimating sources and sinks of $\mathrm{CO}_{2}$ using GOSAT measurements, J. Geophys. Res.-Atmos., 120, 5253-5266, https://doi.org/10.1002/2014JD022962, 2015.

Ialongo, I., Virta, H., Eskes, H., Hovila, J., and Douros, J.: Comparison of TROPOMI/Sentinel 5 Precursor $\mathrm{NO}_{2}$ observations with ground-based measurements in Helsinki, Atmos. Meas. Tech. Discuss., https://doi.org/10.5194/amt-2019-329, in review, 2019.

Janardanan, R., Maksyutov, S., Oda, T., Saito, M., Kaiser, J. W., Ganshin, A., Stohl, A., Matsunaga, T., Yoshida, Y., and Yokota, T.: Comparing GOSAT observations of localized $\mathrm{CO}_{2}$ enhancements by large emitters with inventorybased estimates, Geophys. Res. Lett., 43, 3486-3493, https://doi.org/10.1002/2016GL067843, 2016.

Janssens-Maenhout, G., Crippa, M., Guizzardi, D., Muntean, M., Schaaf, E., Dentener, F., Bergamaschi, P., Pagliari, V., Olivier, J. G. J., Peters, J. A. H. W., van Aardenne, J. A., Monni, S., Doering, U., and Petrescu, A. M. R.: EDGAR v4.3.2 Global Atlas of the three major Greenhouse Gas Emissions for the period 1970-2012, Earth Syst. Sci. Data Discuss., https://doi.org/10.5194/essd-2017-79, 2017.

Jöckel, P., Tost, H., Pozzer, A., Kunze, M., Kirner, O., Brenninkmeijer, C. A. M., Brinkop, S., Cai, D. S., Dyroff, C., Eckstein, J., Frank, F., Garny, H., Gottschaldt, K.-D., Graf, P., Grewe, V., Kerkweg, A., Kern, B., Matthes, S., Mertens, M., Meul, S., Neumaier, M., Nützel, M., Oberländer-Hayn, S., Ruhnke, R., Runde, T., Sander, R., Scharffe, D., and Zahn, A.: Earth System Chemistry integrated Modelling (ESCiMo) with the Modular Earth Submodel System (MESSy) version 2.51, Geosci. Model Dev., 9, 1153-1200, https://doi.org/10.5194/gmd-9-1153-2016, 2016.
Joiner, J.: GEOS-5 FP-IT Assimilation Geo-colocated to OMI/Aura VIS 1-Orbit L2 Support Swath 13x24km V3, https://doi.org/10.5067/Aura/OMI/DATA2033, 2018.

Kleipool, Q. L., Dobber, M. R., de Haan, J. F., and Levelt, P. F.: Earth surface reflectance climatology from 3 years of OMI data, J. Geophys. Res.-Atmos., 113, D18, https://doi.org/10.1029/2008jd010290, 2008.

Konovalov, I. B., Berezin, E. V., Ciais, P., Broquet, G., Zhuravlev, R. V., and Janssens-Maenhout, G.: Estimation of fossil-fuel $\mathrm{CO}_{2}$ emissions using satellite measurements of "proxy" species, Atmos. Chem. Phys., 16, 13509-13540, https://doi.org/10.5194/acp-16-13509-2016, 2016.

Kort, E. A., Frankenberg, C., Miller, C. E., and Oda, T.: Space-based observations of megacity carbon dioxide, Geophys. Res. Lett., 39, L17806, https://doi.org/10.1029/2012GL052738, 2012.

Krotkov, N. A., Lamsal, L. N., Celarier, E. A., Swartz, W. H., Marchenko, S. V., Bucsela, E. J., Chan, K. L., Wenig, M., and Zara, M.: The version $3 \mathrm{OMI} \mathrm{NO}_{2}$ standard product, Atmos. Meas. Tech., 10, 3133-3149, https://doi.org/10.5194/amt10-3133-2017, 2017.

Krotkov, N. A., Lamsal, L. N., Marchenko, S. V., Celarier, E. A., Bucsela, E. J., Swartz, W. H., Joiner, J., and the OMI core team: OMI/Aura Nitrogen Dioxide $\left(\mathrm{NO}_{2}\right)$ Total and Tropospheric Column 1-orbit L2 Swath 13x24 km V003, https://doi.org/10.5067/Aura/OMI/DATA2017, 2018.

Levelt, P. F., van den Oord, G. H. J., Dobber, M. R., Malkki, A., Huib, V., Johan de, V., Stammes, P., Lundell, J. O. V., and Saari, H.: The ozone monitoring instrument, IEEE T. Geosci. Remote, 44, 1093-1101, 2006.

Levelt, P. F., Joiner, J., Tamminen, J., Veefkind, J. P., Bhartia, P. K., Stein Zweers, D. C., Duncan, B. N., Streets, D. G., Eskes, H., van der A, R., McLinden, C., Fioletov, V., Carn, S., de Laat, J., DeLand, M., Marchenko, S., McPeters, R., Ziemke, J., Fu, D., Liu, X., Pickering, K., Apituley, A., González Abad, G., Arola, A., Boersma, F., Chan Miller, C., Chance, K., de Graaf, M., Hakkarainen, J., Hassinen, S., Ialongo, I., Kleipool, Q., Krotkov, N., Li, C., Lamsal, L., Newman, P., Nowlan, C., Suleiman, R., Tilstra, L. G., Torres, O., Wang, H., and Wargan, K.: The Ozone Monitoring Instrument: overview of 14 years in space, Atmos. Chem. Phys., 18, 5699-5745, https://doi.org/10.5194/acp18-5699-2018, 2018.

Liu, F., Zhang, Q., Tong, D., Zheng, B., Li, M., Huo, H., and He, K. B.: High-resolution inventory of technologies, activities, and emissions of coal-fired power plants in China from 1990 to 2010, Atmos. Chem. Phys., 15, 13299-13317, https://doi.org/10.5194/acp-15-13299-2015, 2015.

Liu, F., Beirle, S., Zhang, Q., Dörner, S., He, K., and Wagner, T.: $\mathrm{NO}_{x}$ lifetimes and emissions of cities and power plants in polluted background estimated by satellite observations, Atmos. Chem. Phys., 16, 5283-5298, https://doi.org/10.5194/acp16-5283-2016, 2016.

Liu, F., Beirle, S., Zhang, Q., van der A, R. J., Zheng, B., Tong, D., and He, K.: $\mathrm{NO}_{x}$ emission trends over Chinese cities estimated from OMI observations during 2005 to 2015, Atmos. Chem. Phys., 17, 9261-9275, https://doi.org/10.5194/acp-179261-2017, 2017.

Liu, F., Choi, S., Li, C., Fioletov, V. E., McLinden, C. A., Joiner, J., Krotkov, N. A., Bian, H., Janssens-Maenhout, G., Darmenov, A. S., and da Silva, A. M.: A new global anthropogenic $\mathrm{SO}_{2}$ emis- 
sion inventory for the last decade: a mosaic of satellite-derived and bottom-up emissions, Atmos. Chem. Phys., 18, 1657116586, https://doi.org/10.5194/acp-18-16571-2018, 2018.

$\mathrm{Lu}, \mathrm{Z}$. and Streets, D. G.: Increase in $\mathrm{NO}_{x}$ emissions from Indian thermal power plants during 1996-2010: Unit-based inventories and multisatellite observations, Environ. Sci. Technol., 46, 74637470, https://doi.org/10.1021/es300831w, 2012.

Lu, Z., Streets, D. G., de Foy, B., Lamsal, L. N., Duncan, B. N., and Xing, J.: Emissions of nitrogen oxides from US urban areas: estimation from Ozone Monitoring Instrument retrievals for 2005-2014, Atmos. Chem. Phys., 15, 10367-10383, https://doi.org/10.5194/acp-15-10367-2015, 2015.

Majanne, Y., Korpela, T., Judl, J., Koskela, S., Laukkanen, V., and Häyrinen, A.: Real Time Monitoring of Environmental Efficiency of Power Plants, IFAC-PapersOnLine, 48, 495-500, https://doi.org/10.1016/j.ifacol.2015.12.428, 2015.

Makgato, S. and Chirwa, E.: Characteristics of Thermal Coal used by Power Plants in Waterberg Region of South Africa, Chem. Engineer. Trans., 57, 511-516, 10.3303/CET1757086, 2017.

McLinden, C. A., Fioletov, V., Boersma, K. F., Kharol, S. K., Krotkov, N., Lamsal, L., Makar, P. A., Martin, R. V., Veefkind, J. P., and Yang, K.: Improved satellite retrievals of $\mathrm{NO}_{2}$ and $\mathrm{SO}_{2}$ over the Canadian oil sands and comparisons with surface measurements, Atmos. Chem. Phys., 14, 3637-3656, https://doi.org/10.5194/acp-14-3637-2014, 2014.

Nassar, R., Hill, T. G., McLinden, C. A., Wunch, D., Jones, D. B. A., and Crisp, D.: Quantifying $\mathrm{CO}_{2}$ Emissions From Individual Power Plants From Space, Geophys. Res. Lett., 44, 1004510053, https://doi.org/10.1002/2017GL074702, 2017.

Oda, T., Maksyutov, S., and Andres, R. J.: The Open-source Data Inventory for Anthropogenic $\mathrm{CO}_{2}$, version 2016 (ODIAC2016): a global monthly fossil fuel $\mathrm{CO}_{2}$ gridded emissions data product for tracer transport simulations and surface flux inversions, Earth Syst. Sci. Data, 10, 87-107, https://doi.org/10.5194/essd-10-872018, 2018.

Pretorius, I., Piketh, S., Burger, R., and Neomagus, H.: A perspective on South African coal fired power station emissions, J. Energy South. Afr., 26, 27-40, https://doi.org/10.17159/24133051/2015/v26i3a2127, 2015.

Reuter, M., Buchwitz, M., Hilboll, A., Richter, A., Schneising, O., Hilker, M., Heymann, J., Bovensmann, H., and Burrows, J. P.: Decreasing emissions of $\mathrm{NO}_{x}$ relative to $\mathrm{CO}_{2}$ in East Asia inferred from satellite observations, Nat. Geosci., 7, 792-795, https://doi.org/10.1038/ngeo2257, 2014.

Reuter, M., Buchwitz, M., Schneising, O., Krautwurst, S., O’Dell, C. W., Richter, A., Bovensmann, H., and Burrows, J. P.: Towards monitoring localized $\mathrm{CO}_{2}$ emissions from space: colocated regional $\mathrm{CO}_{2}$ and $\mathrm{NO}_{2}$ enhancements observed by the OCO-2 and S5P satellites, Atmos. Chem. Phys., 19, 9371-9383, https://doi.org/10.5194/acp-19-9371-2019, 2019.

Russell, A. R., Perring, A. E., Valin, L. C., Bucsela, E. J., Browne, E. C., Wooldridge, P. J., and Cohen, R. C.: A high spatial resolution retrieval of $\mathrm{NO}_{2}$ column densities from OMI: method and evaluation, Atmos. Chem. Phys., 11, 8543-8554, https://doi.org/10.5194/acp-11-8543-2011, 2011.

Schneising, O., Heymann, J., Buchwitz, M., Reuter, M., Bovensmann, H., and Burrows, J. P.: Anthropogenic carbon dioxide source areas observed from space: assessment of regional en- hancements and trends, Atmos. Chem. Phys., 13, 2445-2454, https://doi.org/10.5194/acp-13-2445-2013, 2013.

Schoeberl, M. R., Douglass, A. R., Hilsenrath, E., Bhartia, P. K., Beer, R., Waters, J. W., Gunson, M. R., Froidevaux, L., Gille, J. C., and Barnett, J. J.: Overview of the EOS Aura mission, IEEE T. Geosci. Remote, 44, 1066-1074, 2006.

Seinfeld, J. H. and Pandis, S. N.: Atmospheric chemistry and physics: From air pollution to climate change, John Wiley and Sons, New York, 204-275, 2006.

Shaiganfar, R., Beirle, S., Denier van der Gon, H., Jonkers, S., Kuenen, J., Petetin, H., Zhang, Q., Beekmann, M., and Wagner, T.: Estimation of the Paris $\mathrm{NO}_{x}$ emissions from mobile MAXDOAS observations and CHIMERE model simulations during the MEGAPOLI campaign using the closed integral method, Atmos. Chem. Phys., 17, 7853-7890, https://doi.org/10.5194/acp17-7853-2017, 2017.

Shindell, D. and Faluvegi, G.: The net climate impact of coal-fired power plant emissions, Atmos. Chem. Phys., 10, 3247-3260, https://doi.org/10.5194/acp-10-3247-2010, 2010.

Sloss, L.: Efficiency and emissions monitoring and reporting, CCC/188, 40, IEA Clean Coal Centre, London, UK, 2011.

Tong, D., Zhang, Q., Davis, S. J., Liu, F., Zheng, B., Geng, G., Xue, T., Li, M., Hong, C., Lu, Z., Streets, D. G., Guan, D., and $\mathrm{He}, \mathrm{K}$. : Targeted emission reductions from global superpolluting power plant units, Nature Sustainability, 1, 59-68, https://doi.org/10.1038/s41893-017-0003-y, 2018a.

Tong, D., Zhang, Q., Davis, S. J., Liu, F., Zheng, B., Geng, G., Xue, T., Li, M., Hong, C., Lu, Z., Streets, D. G., Guan, D., and He, K.: The Global Power Emissions Database, available at: http://www. meicmodel.org/dataset-gped.html (last access: 1 April 2019), 2018b.

U.S. Energy Information Administration (US EIA): Electric Power Annual 2017, available at: https://www.eia.gov/electricity/ annual/pdf/epa.pdf (last access: 11 April 2019), 2018.

U.S. Environmental Protection Agency (US EPA): Compilation of Air Pollutant Emission Factors, AP-42, Fifth Edition, Volume 1, Chapter 1, Washington, D. C., available at: https://www3.epa.gov/ttn/chief/ap42/ch01/index.html (last access: 20 March 2019), 2009.

U.S. Environmental Protection Agency (US EPA), Air Markets Program Data, available at: https://ampd.epa.gov/ampd/ (last access: 10 March 2019), 2017.

U.S. Environmental Protection Agency (US EPA): Technical support document for eGRID with year 2016 data (the Emissions \& Generation Resource Integrated Database), Washington, D.C., 2018.

Valin, L. C., Russell, A. R., and Cohen, R. C.: Variations of $\mathrm{OH}$ radical in an urban plume inferred from $\mathrm{NO}_{2}$ column measurements, Geophys. Res. Lett., 40, 1856-1860, https://doi.org/10.1002/grl.50267, 2013.

Varon, D. J., Jacob, D. J., McKeever, J., Jervis, D., Durak, B. O. A., Xia, Y., and Huang, Y.: Quantifying methane point sources from fine-scale satellite observations of atmospheric methane plumes, Atmos. Meas. Tech., 11, 5673-5686, https://doi.org/10.5194/amt-11-5673-2018, 2018.

Veefkind, J. P., Aben, I., McMullan, K., Förster, H., de Vries, J., Otter, G., Claas, J., Eskes, H. J., de Haan, J. F., Kleipool, Q., van Weele, M., Hasekamp, O., Hoogeveen, R., Landgraf, J., Snel, R., Tol, P., Ingmann, P., Voors, R., Kruizinga, B., Vink, R., Visser, 
H., and Levelt, P. F.: TROPOMI on the ESA Sentinel-5 Precursor: A GMES mission for global observations of the atmospheric composition for climate, air quality and ozone layer applications, Remote Sens. Environ., 120, 70-83, 2012.

Velazco, V. A., Buchwitz, M., Bovensmann, H., Reuter, M., Schneising, O., Heymann, J., Krings, T., Gerilowski, K., and Burrows, J. P.: Towards space based verification of $\mathrm{CO}_{2}$ emissions from strong localized sources: fossil fuel power plant emissions as seen by a CarbonSat constellation, Atmos. Meas. Tech., 4, 2809-2822, https://doi.org/10.5194/amt-4-2809-2011, 2011.

Wang, S., Zhang, Y., Hakkarainen, J., Ju, W., Liu, Y., Jiang, F., and $\mathrm{He}, \mathrm{W} .:$ Distinguishing anthropogenic $\mathrm{CO}_{2}$ emissions From different energy intensive industrial sources using OCO-2 observations: A case study in Northern China, J. Geophys. Res.-Atmos., 123, 9462-9473, https://doi.org/10.1029/2018jd029005, 2018.
Wheeler, D. and Ummel, K.: Calculating CARMA: Global estimation of $\mathrm{CO}_{2}$ emissions from the power sector, Center for Global Development, Working Paper 145, 2008.

Yokota, T., Yoshida, Y., Eguchi, N., Ota, Y., Tanaka, T., Watanabe, H., and Maksyutov, S.: Global Concentrations of $\mathrm{CO}_{2}$ and $\mathrm{CH}_{4}$ Retrieved from GOSAT: First Preliminary Results, SOLA, 5, 160-163, https://doi.org/10.2151/sola.2009-041, 2009. 